\title{
Clay Mineralogy of Pleistocene Lake Tecopa, Inyo County, California
}

GEOLOGICALSURVEY PROFESSIONAL PAPER 1061
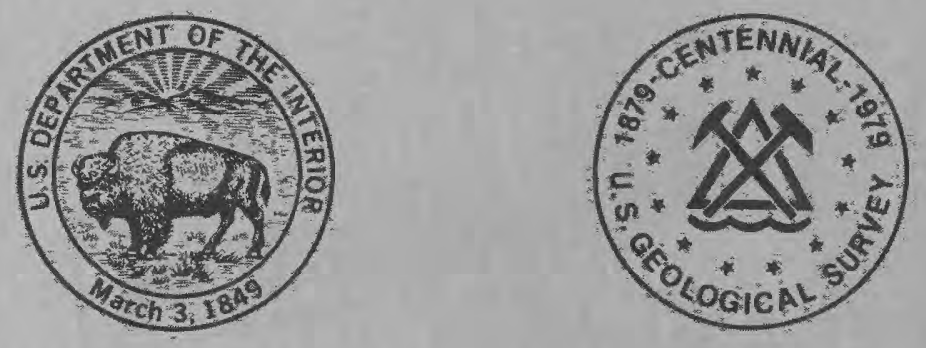



\section{Clay Mineralogy of Pleistocene Lake Tecopa, Inyo County, California}

By HARRY C. STARKEY and PAUL D. BLACKMON

GEOLOGICAL S U R VEY PROFESSIONAL PAPER 1061

In a saline lake with $p H$ above 8.5

authigenic sepiolite and detrital

lithium-bearing saponite were

deposited in mudstones which

were interlayered with

volcanic tuffs

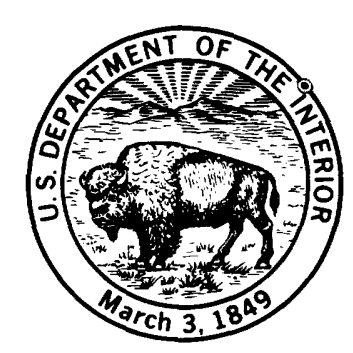

UNITED STATES GOVERNMENT PRINTING OFFICE, WASHINGTON:1979 


\title{
UNITED STATES DEPARTMENT OF THE INTERIOR
}

\author{
CECIL D. ANDRUS, Secretary
}

\section{GEOLOGICAL SURVEY}

H. William Menard, Director

Library of Congress Cataloging in Publication Data

Starkey, Harry C.

Clay mineralogy of Pleistocene Lake Tecopa, Inyo County, California.

(Geological Survey Professional Paper 1061)

Bibliography: p. 33

Supt. of Docs. no.: I 19.16:1061

1. Clay minerals-California-Inyo Co. 2. Meerschaum-California-Inyo Co. 3. Saponite-California-Inyo Co.

4. Saline waters-California-Inyo Co.

1.. Blackmon, Paul D., joint author. II. Title. III. Series: United States Geological Survey Professional Paper 1061.

QE3 89.625.S73 $\quad 549^{\prime} .6 \quad 77-608318$

For sale by the Superintendent of Documents, U.S. Government Printing Office

Washington, D.C. 20402

Stock Number 024-001-03185-0 


\section{CONTENTS}

\begin{tabular}{|c|c|c|}
\hline Page & & Page \\
\hline Abstract .... & Nonclay minerals-Continued & \\
\hline Introduction $\ldots \ldots \ldots \ldots \ldots \ldots \ldots$ & Other minerals ........... & 18 \\
\hline Location and geographic setting... & Clay minerals ............ & 20 \\
\hline Acknowledgments ............ & Chlorite and chlorite-mica . & 20 \\
\hline Scope of investigation ........ & Mica and illite .......... & 20 \\
\hline Previous work $\ldots \ldots \ldots \ldots \ldots$ & Lithian saponite. & 23 \\
\hline & & 25 \\
\hline Geology of the basin.. & Sepiolite...$\ldots \ldots \ldots \ldots$ & 25 \\
\hline Description of the mudstones and siltstones ................ & Tecopa basin occurrence $\ldots \ldots \ldots \ldots \ldots \ldots \ldots \ldots$ & 25 \\
\hline Laboratory methods $\ldots \ldots \ldots \ldots \ldots \ldots \ldots \ldots \ldots \ldots \ldots \ldots$ & Previous work on sepiolite $\ldots \ldots \ldots \ldots \ldots \ldots \ldots \ldots$ & 26 \\
\hline 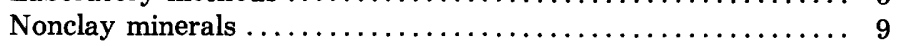 & Modes of sepiolite formation .................. & 26 \\
\hline Quartz and plagioclase feldspar $\ldots \ldots \ldots \ldots \ldots \ldots \ldots \ldots \ldots$ & Sources of magnesium and silica ........ & 27 \\
\hline 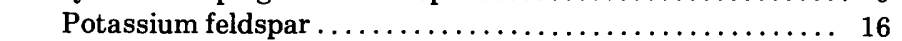 & Sepiolite formation in Lake Tecopa.$\ldots \ldots \ldots \ldots \ldots$ & 30 \\
\hline 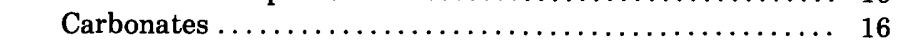 & 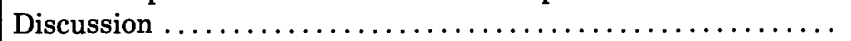 & 31 \\
\hline 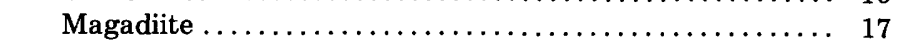 & $\ldots \ldots \ldots \ldots \ldots \ldots \ldots \ldots \ldots \ldots \ldots \ldots$ & 31 \\
\hline Zeolites and amorphous material $\ldots \ldots \ldots \ldots \ldots \ldots \ldots \ldots, 18$ & Conclusions . & 31 \\
\hline Saline minerals $\ldots \ldots \ldots \ldots \ldots \ldots \ldots \ldots \ldots \ldots \ldots \ldots \ldots, 18$ & ferences cited & \\
\hline
\end{tabular}

\section{ILLUSTRATIONS}

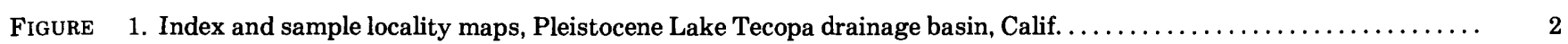

2. Photograph from sample locality 54 looking northeast toward Shoshone, Calif. . . . . . . . . . . . . . . . . . . . .

3. Generalized stratigraphic section of the Pleistocene Lake Tecopa deposits . . . . . . . . . . . . . . . . . . . . . . . .

4. Photograph of sample locality 44 showing gravel mixed with clay $\ldots \ldots \ldots \ldots \ldots \ldots \ldots \ldots \ldots \ldots \ldots \ldots$

5. Flow sheet for laboratory procedures used for mineral identification of Pleistocene Lake Tecopa deposits ..........

6-11. Transmission electron micrographs:

6. Suspended sepiolite

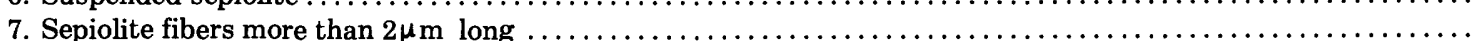

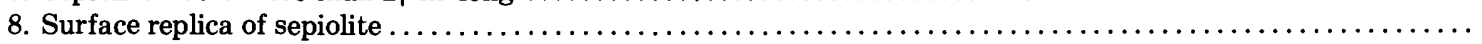

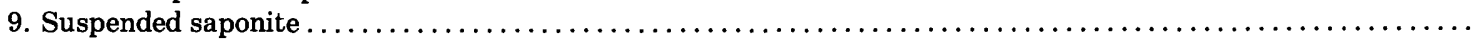

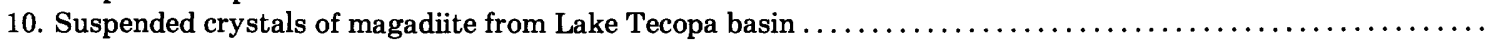

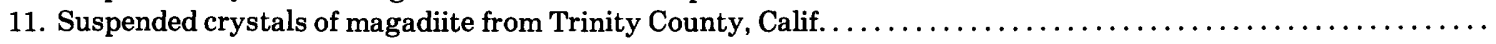

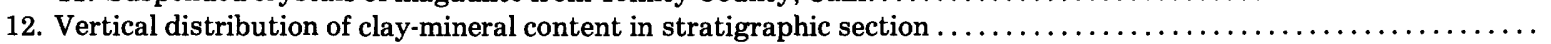

13. X-ray diffraction curves of typical gradation from mica to mixed-layer mica-saponite $\ldots \ldots \ldots \ldots \ldots \ldots \ldots \ldots \ldots$

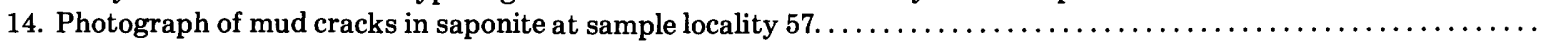

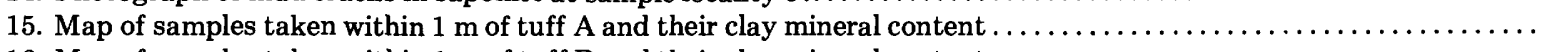

16. Map of samples taken within $1 \mathrm{~m}$ of tuff $\mathrm{B}$ and their clay mineral content............ 


\section{TABLES}

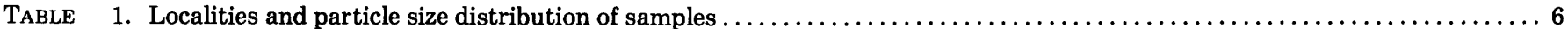

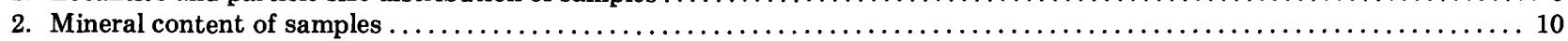

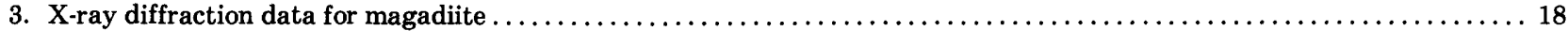

4. Comparison of X-ray diffraction spacings of sepiolite and saponite from Pleistocene Lake Tecopa with those of

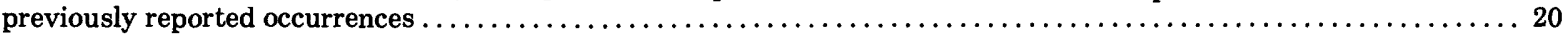

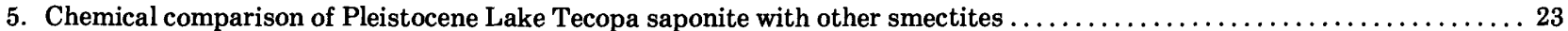

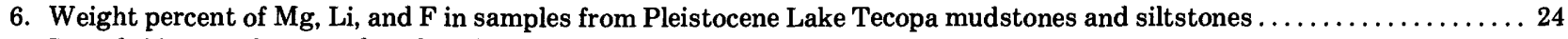

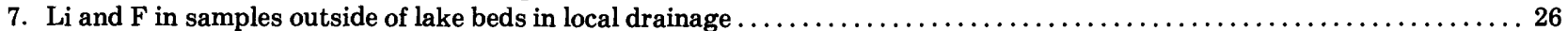




\title{
CLAY MINERALOGY OF PLEISTOCENE LAKE TECOPA, INYO COUNTY, CALIFORNIA
}

\author{
By Harry C. Starkey and Paul D. Blackmon
}

\begin{abstract}
Pleistocene Lake Tecopa in southeastern Inyo County, Calif., was formed when the Amargosa River was blocked at the southern end of its valley. The lake acted as a settling basin for detrital material being transported by the river. This detritus consisted of clays, quartz, feldspars, and micas which became mudstones and siltstones. These mudstones and siltstones, much eroded and dissected after the draining of the lake, extend over the entire basin and are interbedded with tuffs formed by the intermittent deposition of volcanic ashfalls in the former lake waters. These lightcolored mudstones and siltstones are tough and well indurated and break with a conchoidal fracture.

The predominant clay mineral in these detrital beds is a lithiumbearing saponite, which is found not only in the lake beds but also in the area beyond the boundaries of the lake, especially in fluvial deposits in the drainage basin of the Amargosa River to the north. This saponite does not contain enough lithium to be classified as a hectorite, and we have observed no indications that this clay consists of a mixture of two phases, such as hectorite and a diluent.

Some authigenic dioctahedral montmorillonite, found only in small quantities close to the tuffs, was formed by alteration of the volcanic glass of the tuffs and was then admixed with the overlying or underlying detrital clays.

The only authigenic clay-type mineral found in any significant quantity is sepiolite, found near the edges of the lake basin and stratigraphically located mainly within a meter of the two uppermost tuffs. This sepiolite probably was precipitated when silica became available to the magnesium-bearing lake water through dissolution of the volcanic ash. Precipitation of sepiolite probably did not occur within the tuffs owing to the presence of alumina in solution. Zeolites were produced there and sepiolite formed outside the margins of the tuffs.

Also formed by the high-pH lake waters were water-soluble minerals, which were found widely dispersed in crusts or streaks on the clays. Much of the calcite was likely precipitated from the lake waters, especially near the north end of the lake where calciumbearing fresh water came into contact with the $\mathrm{CO}_{2}$-rich lake waters.

Magadiite, a sodium silicate mineral reported only twice previously in the United States, was found in small quantities in the southern end of the basin. This mineral is indicative of a minimum pH of 8.5.

The authigenic minerals formed in the lake reflect the presence of silica-rich tuffs and the high-pH, alkaline character of the lake waters.
\end{abstract}

\section{INTRODUCTION LOCATION AND GEOGRAPHIC SETTING}

The basin of former Pleistocene Lake Tecopa, in southeastern Inyo County, Calif., is located in the Mojave Desert about $32 \mathrm{~km}$ east of Death Valley National Monument within Tps. 20, 21, and 22 N., and Rs. 6 and $7 \mathrm{E}$. The area is shown in figure 1 . The nearest large city is Las Vegas, Nev., which is located about $97 \mathrm{~km}$ to the east.

The town of Shoshone is located in the northern part of the basin, and the town of Tecopa is located in the southern part; Shoshone is on State Route 127, which runs generally north-south through the basin.

The lake basin is bounded on the west by Dublin Hills, Ibex Hills, and the southern part of the Greenwater Range and on the east by the southern parts of the Nopah Range and Resting Spring Range. To the south are the Sperry Hills through which the Amargosa River flows, draining the study area.

The lake beds cover an area about 18 by 23 kilometers. The elevation of lowest exposures of the beds is at about $396 \mathrm{~m}$ near the south end of the lake, and the highest beds are at about $549 \mathrm{~m}$ at the margins of the lake. The hills and mountain ranges to the east and west of the basin have elevations of about 914-1,219 m. Sperry Hills to the south are about 610-762 $\mathrm{m}$ above sea level.

\section{ACKNOWLEDGMENTS}

We gratefully acknowledge the help of those members of the U.S. Geological Survey who furnished technical assistance during this study. Elaine L. Brandt, (Mrs.) Johnnie Gardner, John C. Hamilton, Violet Merritt, Wayne Mountjoy, and Daniel R. Norton supplied the various chemical analyses. Toribio G. Manzanares did most of the fractionations and ran 


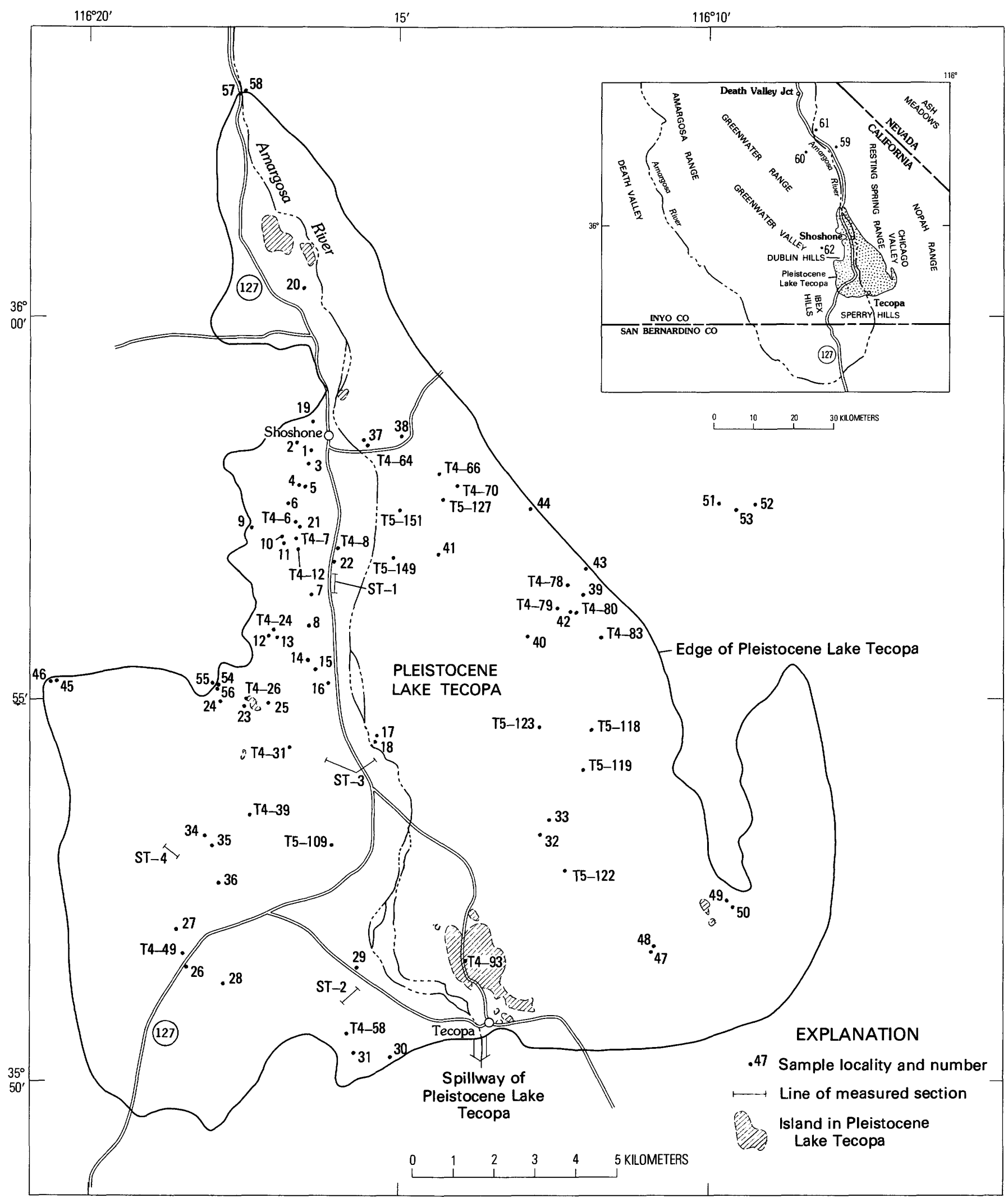

FiguRE 1.-Index and sample locality maps, Pleistocene Lake Tecopa drainage basin, California. 
most of the X-ray patterns. Donald C. Noble, now at Michigan Tech University, provided data on unaltered glasses from Nevada.

\section{SCOPE OF INVESTIGATION}

This report is concerned primarily with the identification, distribution, and origin of the clay minerals found in the Lake Tecopa basin. It also discusses the types and amounts of other minerals present. The Lake Tecopa basin is suited for this type of study because: (1) it covers a relatively small area of about 18 by $23 \mathrm{~km}$, (2) the clay beds are separated by tuffs which can be followed easily and, (3) the clay beds are dissected by gullies so that a few tens of meters of clays can be sampled without drilling. A total of 158 samples from 94 sample sites were examined, the locations of which are shown in figure 1 . Samples that were collected from the area outside the basin are shown in the area covered by the map in the inset. The word "basin" is used in this report to mean only the area actually covered by the waters of Pleistocene Lake Tecopa.

\section{PREVIOUS WORK}

Numerous geologic investigations have been carried out in the Lake Tecopa area. Melhase (1926) described the geology and the mining operations of "amargosite," which he claimed to have named in 1920. This clay, which is actually montmorillonite, at the time was known also as "soap rock" or "natural soap." Noble, Mansfield, and others (1922) described the mudstones and saline deposits in their investigations of the nitrate beds. Noble (1926) gave a brief description of the geology of part of the Amargosa valley in his investigation of a colemanite deposit near Shoshone. Later (1934) he gave a more complete description of the rock formations in the area. Dietrich $(1928$, p. 88$)$ described the clay beds as trending north and south, as being 1.8-2.4 $\mathrm{m}$ thick, and as being overlain by $1.2-1.8 \mathrm{~m}$ of volcanic ash. Blackwelder $(1936,1954)$ gave brief outlines of the general geology and history of the Lake Tecopa area, pointing out that the deposits on the lake floors had been deeply entrenched and eroded after the lake drained. Wright and Troxel (1954) described the lake beds as mostly siltstone with subordinate layers of volcanic ash and bentonite clay. Although in the past the clays in the beds of Lake Tecopa have been described by several authors, the scope of the work often was limited by the available analytical methods. Identifications and conclusions were based on physical and chemical properties and upon the commercial uses to which the clays could be put.
Sheppard and Gude (1968), in their study of the authigenic silicate minerals in the tuffs of Lake Tecopa, described those tuffs in detail and we will use them as stratigraphic markers for the present study. They reported the occurrence of sepiolite in two of their samples, but they noted that neither Droste (1961) nor Kerr and Langer (1965) had reported sepiolite in their studies of other playa clays of the Mojave Desert. Sepiolite, however, is known to occur in desert lakes of high salinity (Bradley, 1930; Schroter and Campbell, 1942; Hardie, 1968; Parry and Reeves, 1968). The nearest probable occurrence of sepiolite to Lake Tecopa, known to the present authors, is that reported by Foshag and Woodford (1936). They state, "In the bentonitic clay of Ash Meadows near Shoshone, Calif., there are numerous lumps of mixed lime, magnesium carbonates and a magnesium silicate close to sepiolite," but they do not give an exact sample site location. Ash Meadows is about $40 \mathrm{~km}$ north of Shoshone (fig. 1).

\section{GEOLOGY OF THE BASIN}

Most of the geologic investigations that have been made of Lake Tecopa in the past have been primarily concerned with the saline deposits and especially with the possiblity of finding nitrate deposits. The reports of these investigations have also described the general geology of the area surrounding Lake Tecopa.

Sheppard and Gude (1968) gave a detailed report on the mineralogy of the tuffs associated with the mudstones, and an excellent review of the previous geologic work in the area. Therefore, only a brief description will be given here to acquaint the reader with the mudstones in the basin. For a more complete understanding of the geology, the works of Bailey (1902), Campbell (1902), Thompson (1929), Miller (1946), Mason (1948), and Blanc and Cleveland (1961a,b) should also be consulted.

The Amargosa River, the headwaters of which arise in Pahute Mesa, about $45 \mathrm{~km}$ north of Beatty, Nev., is the principal surface drainage of the Death Valley region. Its channel extends southward across the California-Nevada State line and through the area under study before it turns northwest into Death Valley. The river is mostly dry except for short distances where water is supplied by the springs located at Shoshone and Tecopa, Calif., and by infrequent heavy rains. The Greenwater Valley enters the Lake Tecopa basin from the west, and the Chicago Valley enters from the east. Both, however, have small drainage areas.

The Amargosa River has eroded the mudstones which were deposited in Lake Tecopa when, during 
Pleistocene time, the river was blocked south of the site of the present town of Tecopa. These mudstones appear to be almost horizontal but have a definite slight dip toward the center of the basin. This dip was probably produced by the original slope of the basin floor and by postdepositional compaction. Toward the center of the basin, near the river, the clay beds have been eroded to a low, hummocky surface. Away from the center of the basin, the hummocks become progressively higher and then become buttes capped with gravel which, near the margins of the basin, coalesce to form gravel-capped pediments dissected by steep-sided washes with gravelly alluvium covering the bottoms (fig. 2). The washes, which are as much as $9 \mathrm{~m}$ deep make traverse difficult but provide excellent exposures for the study of the mudstones. The gravel covering the buttes, mesas, and pediments has developed a thin covering of desert varnish.

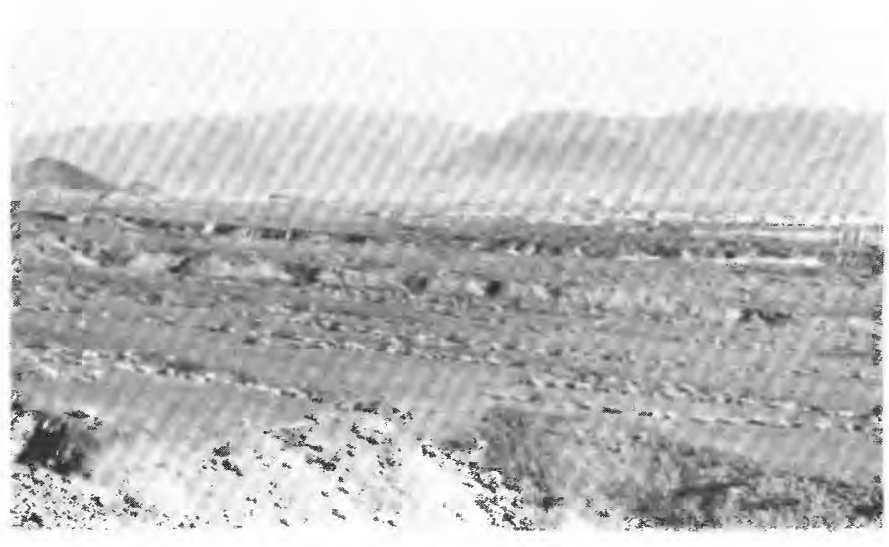

FIGURE 2.-View from sample locality 54 , looking northeast toward Shoshone. Washes in foreground and middle distance are eroding gravel-capped pediments covered with desert varnish. Light area in the middle distance is central portion of the Pleistocene Lake Tecopa basin where surface is eroded away exposing clays beneath.

\section{DESCRIPTION OF THE MUDSTONES AND SILTSTONES}

A generalized section of the stratigraphy is shown in Figure 3. The uppermost sample collected in the lake beds for this study was located about $12 \mathrm{~m}$ above tuff A. The lowest lake beds are not exposed. The beds have a more or less uniform gentle dip toward the center of the basin. The distances between the bottom of tuff A and the top of tuff $B$ ranged from 6 to $8.5 \mathrm{~m}$ and the distance between the bottom of tuff $B$ and the top of tuff $\mathrm{C}$ was approximately $23 \mathrm{~m}$. The lowermost sample was collected from $7.6 \mathrm{~m}$ below tuff $C$. The tuffs range in thickness from several centimeters to about $4 \mathrm{~m}$.

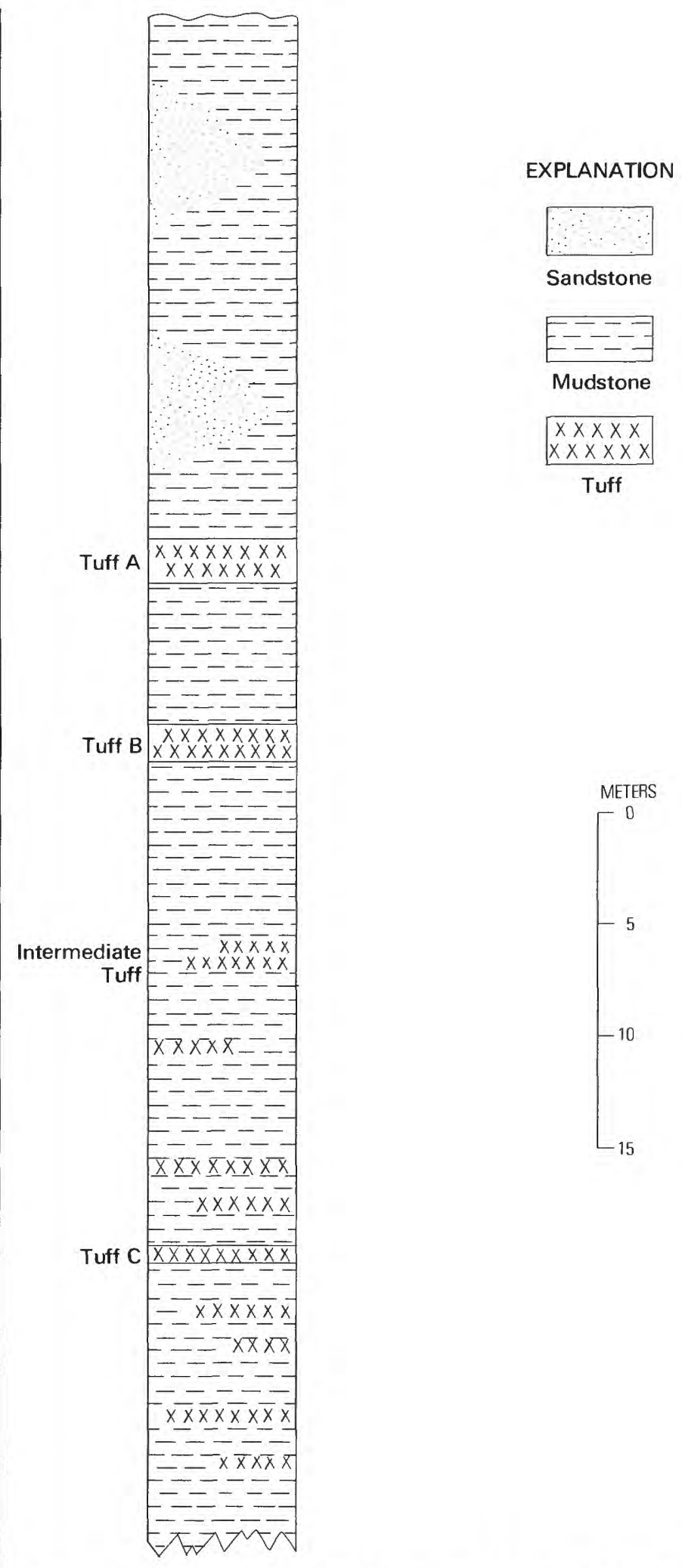

Figure 3.-Generalized stratigraphic section of the Pleistocene Lake Tecopa deposits depicting relationships of the principal tuffs to the mudstones containing the clays (modified from Sheppard and Gude, 1968). 
Near the center of the basin, erosion has been more complete leaving gently rounded hills covered with clay, some of which have a "popcorn" surface. Sheppard and Gude (1968) attribute this "popcorn" appearance to the weathering of montmorillonite-rich mudstones.

The mudstones become more silty and sandy toward the margin where they are mixed with alluvial material washed out from the higher land surrounding the basin (fig. 4). Toward the center of the basin where the mudstones contain less silt and sand, they are indurated and are very tough. These clays break with a conchoidal or subconchoidal fracture, but some are almost impossible to sample unless a sledge and moil are used.

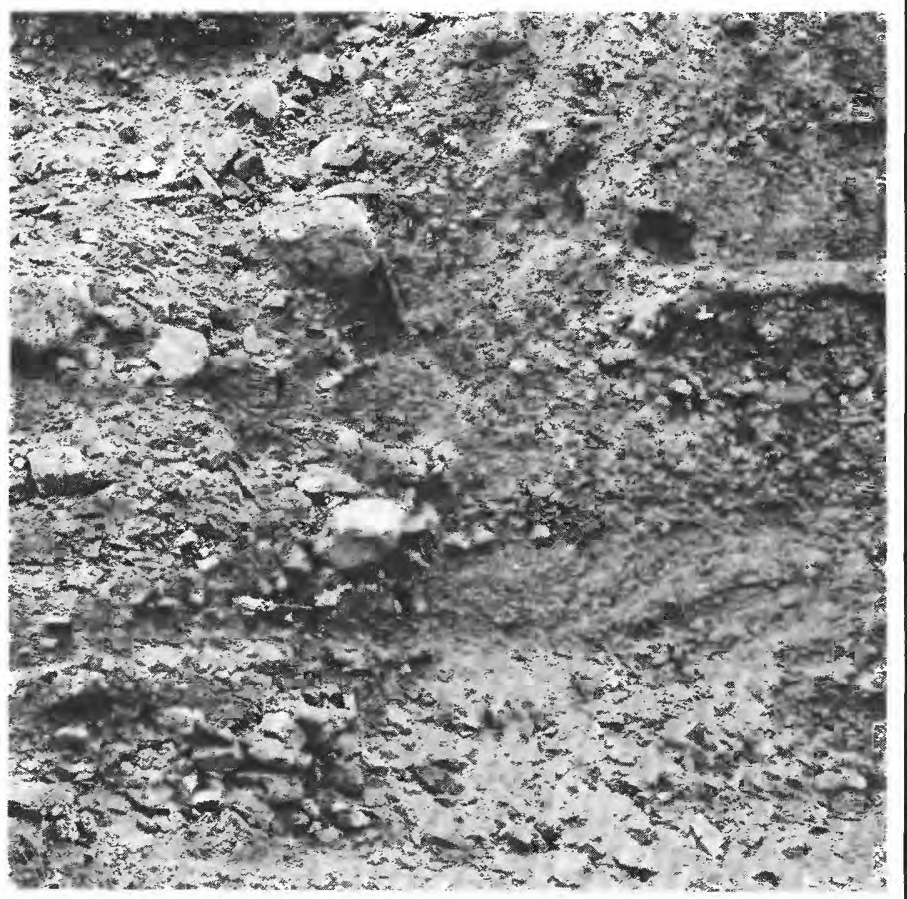

FIGURE 4.-View of sample locality 44 showing gravel mixed with clay.

The colors of the clays are pastel and vary from shades of white to buff, yellow, green, brown, or red. Some of the samples contain white veinlets or specks which have been identified as calcite or amorphous silica, and some contain small black specks of biotite or manganese oxide.

\section{LABORATORY METHODS}

A flow sheet (fig. 5) is shown which outlines the basic procedures used to prepare and analyze the samples. The samples were soaked in water for as much as a week, during which time the more indurated samples were crushed lightly with a rubber pestle. They were then disaggregated by agitation in a mechanical stirrer for 10 minutes and the resulting slurry was put through a 230 -mesh sieve to remove the sand. The clay and silt were then separated by centrifugation according to Stokes' Law. The sand and silt fractions and an aliquot of the clay slurry were dried and weighed to determine percent composition. A portion of the clay slurry was sedimented onto unglazed porcelain tiles by vacuum to obtain oriented aggregates for use in the $\mathrm{X}$-ray analyses of the clays. The salt solutions and the glycerine used to characterize the clay minerals were applied to the surface of the clay-coated tiles by pipet and were sucked through the sample by vacuum.

The X-ray diffraction patterns of the randomly oriented total samples and of the various fractions were compared with standard patterns for identification and estimation of the nonclay minerals present. To identify the clays the oriented aggregates were treated with glycol to expand the smectite layers, were heated to $400^{\circ} \mathrm{C}$ to collapse the smectite layers, and then were heated to $550^{\circ} \mathrm{C}$ to destroy any kaolinite and to increase the intensity of the 001 chlorite reflection. Glycerine treatments of $\mathrm{KC1}$ - and $\mathrm{MgCl}_{2^{-}}$ saturated oriented aggregates were discontinued when they did not indicate the presence of any vermiculite.

The sample numbers, localities, and the results of the fractionation procedure, plus the percentages of water-soluble material present, are listed in table 1. It will be noted that not all the sums of the various fractions and the water-soluble materials total 100 percent. Part of this error is due to timing of determinations: the determinations of the water adsorbed on the clays were not always made at the same time that the total samples were weighed for fractionation. The adsorbed water varied with the relative humidity, especially in those samples containing considerable amounts of zeolites.

The amounts of water-soluble material present were determined by the specific conductance of leachates or by gravimetric measurements of evaporated leachates. Almost all samples gave some indication, however slight, of the presence of salts although most of them indicated no more than 1 percent. The amounts of water-soluble material are also reported, as parts in ten, with the other minerals determined by X-ray diffraction (table 2).

Small variations in the amounts of mineral present are not significant. The wide range of composition, the presence of many minerals in one sample, the veiling of small amounts of clay minerals in the presence of others, the varying degrees of orientation, and the 


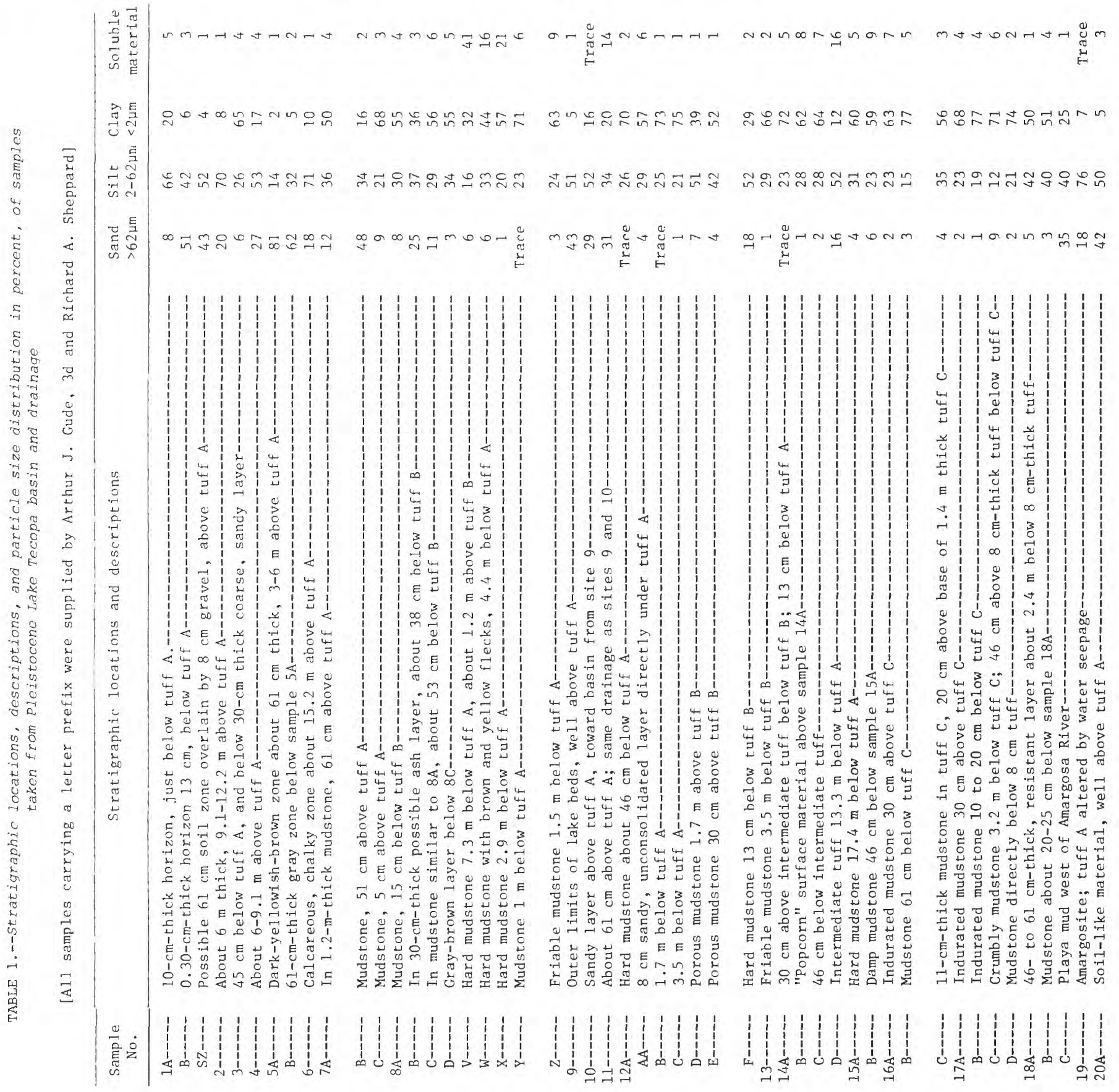




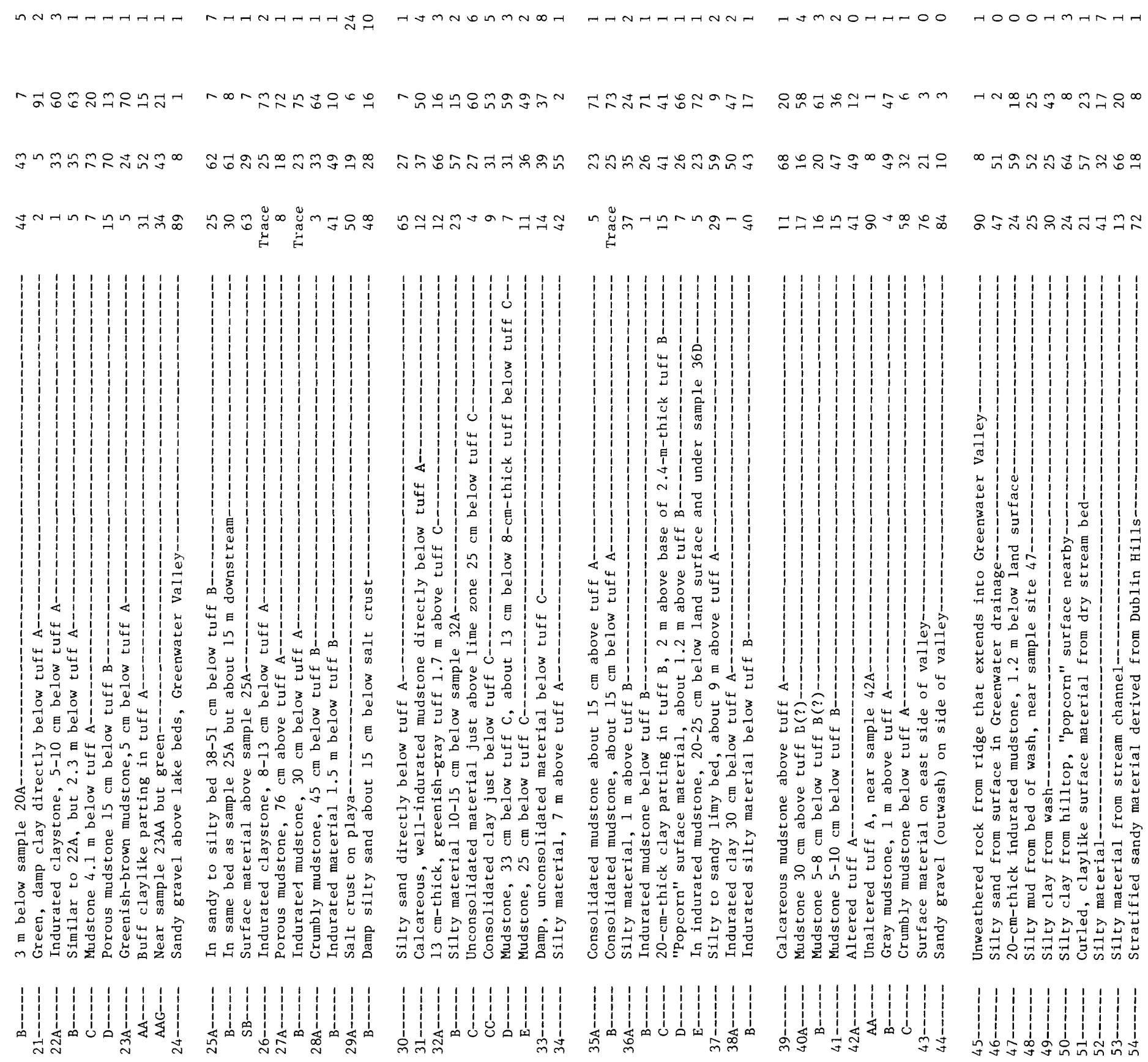



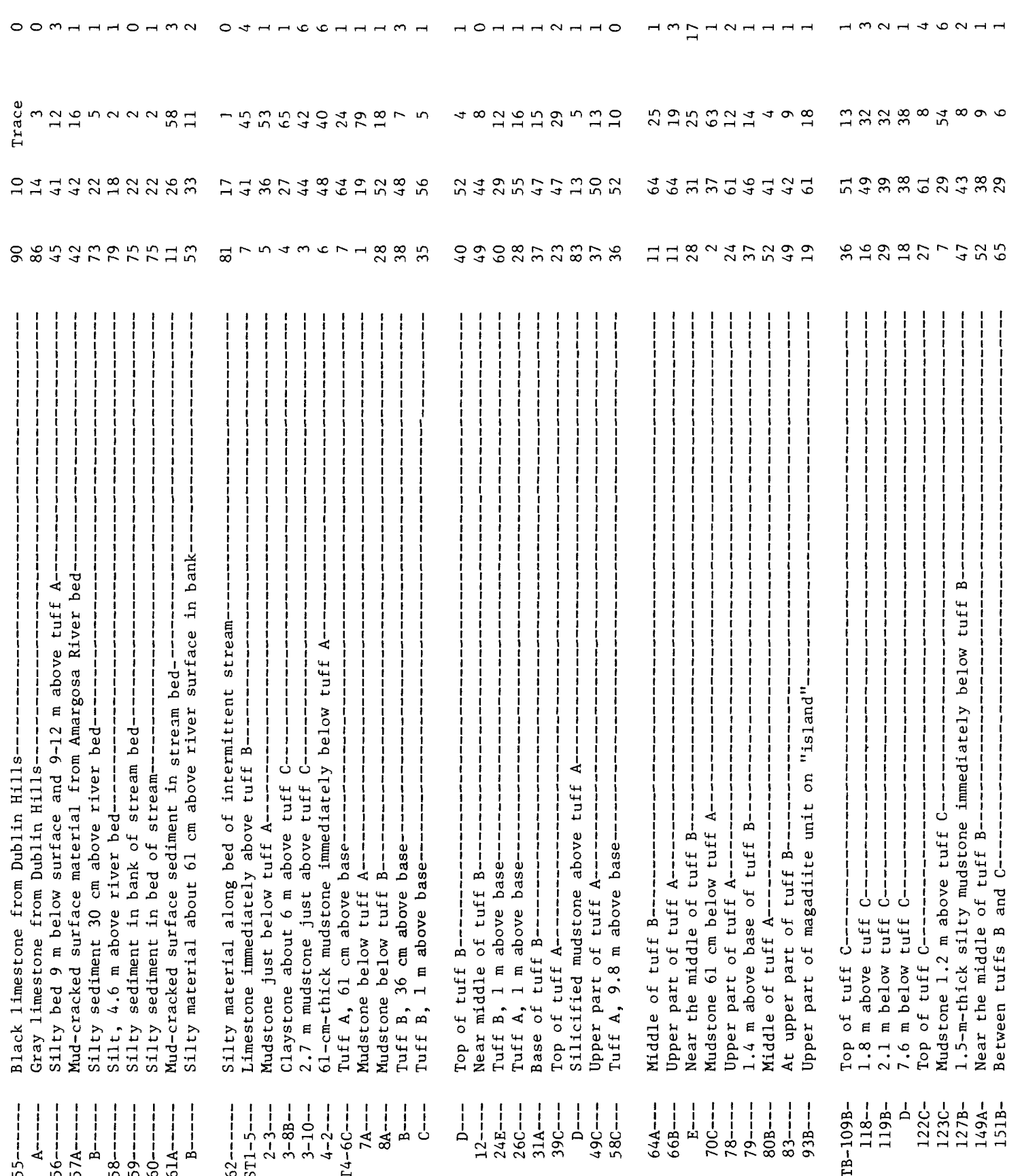


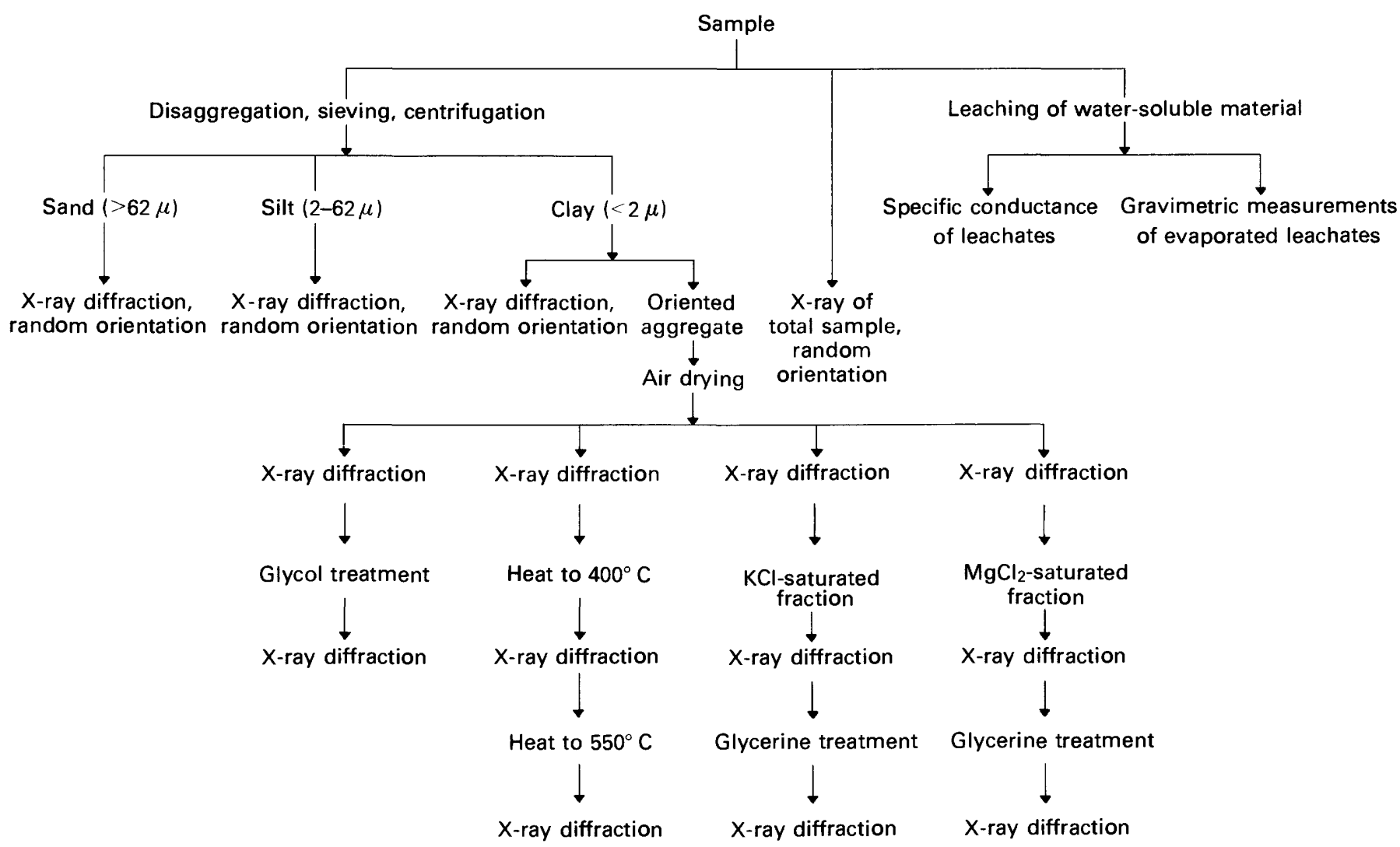

FIgURE 5.-Flow sheet illustrating procedures used for mineral identification.

sampling irregularities make comparisons of small amounts subject to error.

Chemical determinations were made as needed when $\mathrm{X}$-ray determinations were inconclusive. For instance, when single small peaks at $30.4^{\circ} 2 \theta$ on the diffraction patterns indicated possible manganocalcite, the carbonates were removed by dilute hydrochloric acid. Qualitative manganese determinations were made on the resulting solutions.

The amount of amorphous material in the clay-size fraction was difficult to estimate either optically or from X-ray patterns. Therefore, samples appearing to contain more than two parts in ten of amorphous material were boiled for $2 \frac{1}{2}$ minutes in $0.5 \mathrm{~N}$ sodium hydroxide, according to Mallory's (1965) method, and the weight loss sustained was reported as amorphous material, after the percentages of previously determined water-soluble material were subtracted.

Transmission electron micrographs (figs. 6-9) were made to illustrate the morphology and to confirm the presence of the different types of clay minerals. X-ray diffractograms and chemical analyses were made of concentrations of individual minerals to better determine their characteristics.

\section{NONCLAY MINERALS}

Although this investigation is primarily concerned with clay mineralogy, identification of the nonclay minerals is needed, because they may be either a source of materials necessary for the formation of authigenic clays or indicators of detrital origins.

\section{QUARTZ AND PLAGIOGLASE FELDSPAR}

Quartz, which is mainly detrital, is found in most samples but only in small quantities, the largest amount being the 3 parts in 10 found in sample 47 . This sample was taken in the area where sediments from Chicago Valley were brought into the lake basin. In general, the amounts of quartz are highest near the edges of the basin, at the northern end where the Amargosa River enters the basin, and near the junctions of the basin with Greenwater Valley and with Chicago Valley.

Stratigraphically, the greatest amounts of quartz are found in the youngest sediments above tuff A. Between tuff $A$ and tuff $B$ (fig. 3) there appears to be a general decrease in quantity of quartz, but in the 7.6 meters between tuff $B$ and the intermediate tuff still 


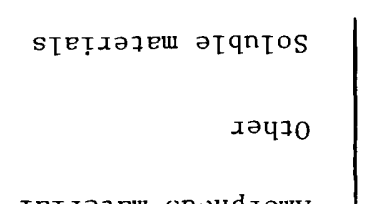

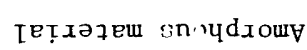

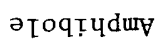

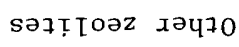

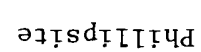

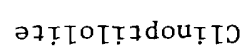

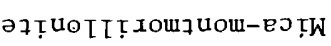

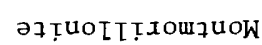

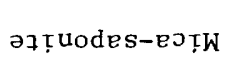

ว7țuodes

Eoț

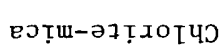

วาเฺอโบว

วาเโTọdas

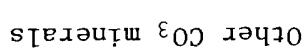

วา ฺ̣moLod

วาธุโอร

zedstigt-x

esejooțetd

zaxen

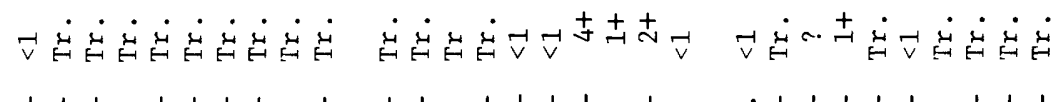

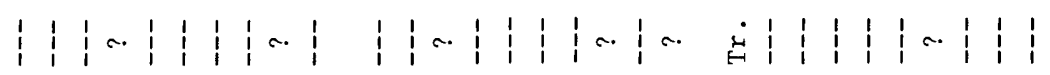

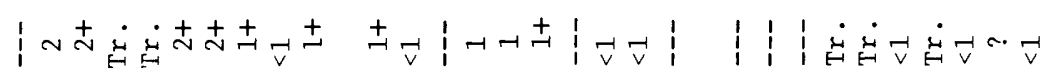
我草

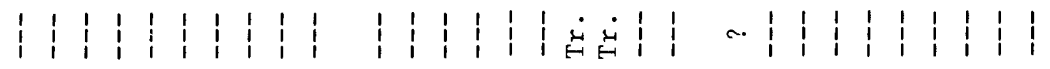

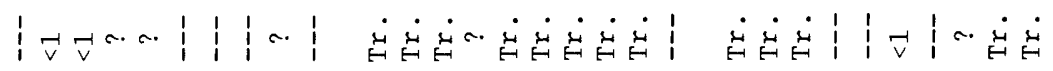

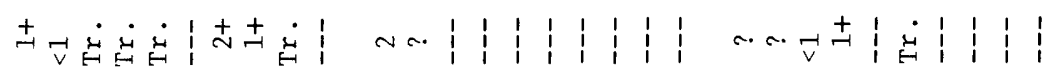

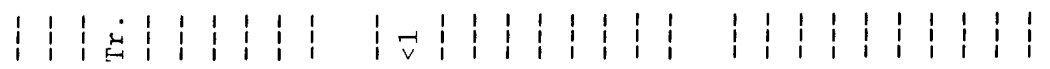

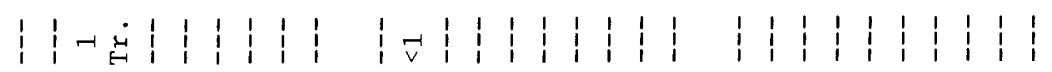

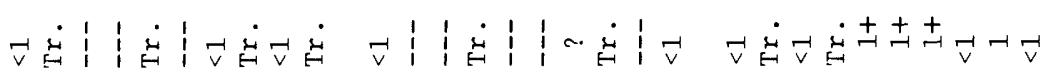

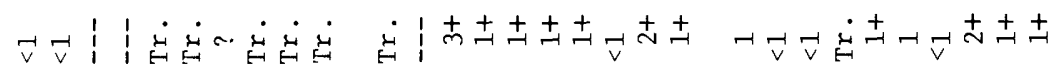

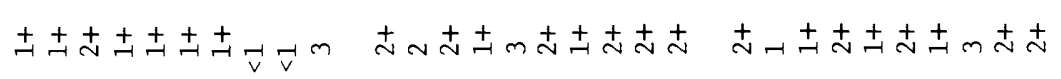

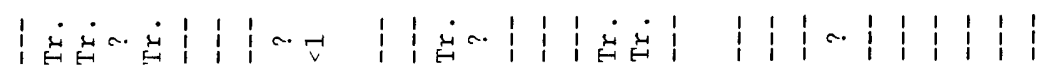
|店点

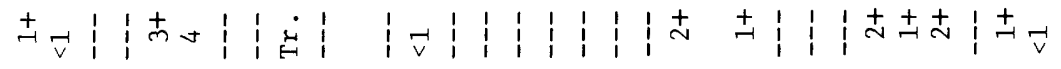
|

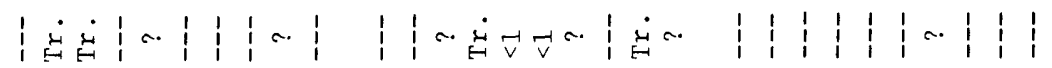

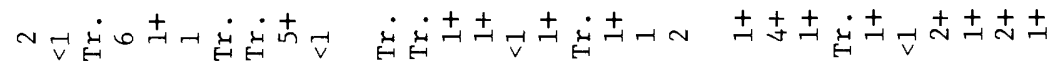

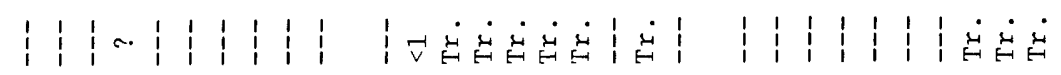

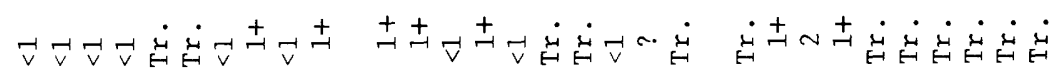

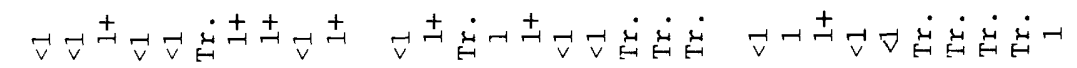

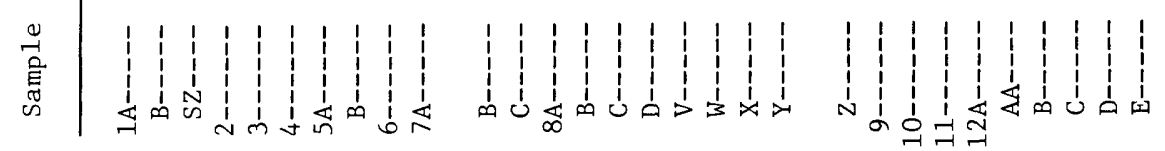




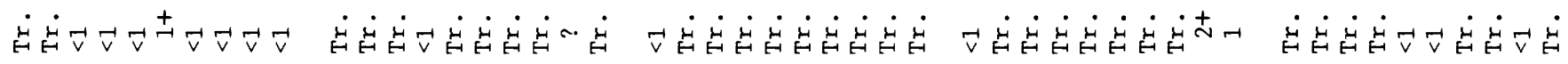

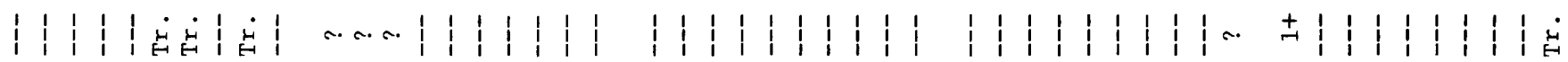

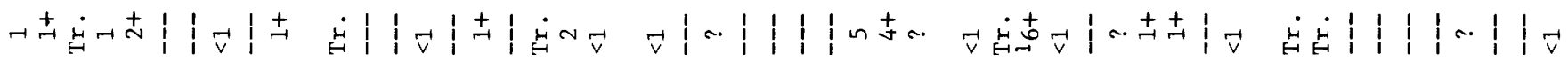

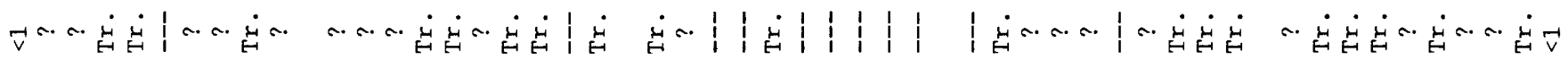

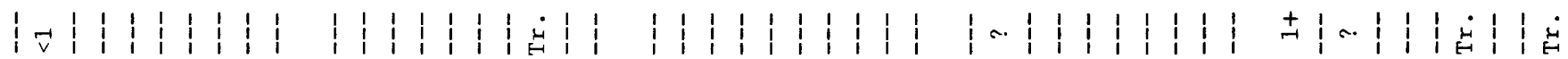

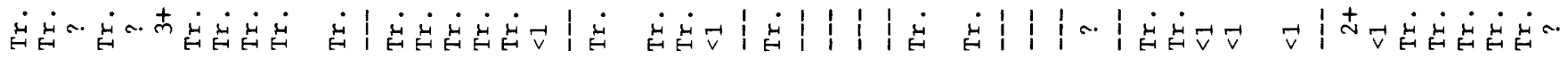

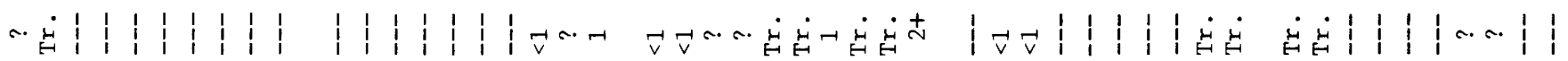

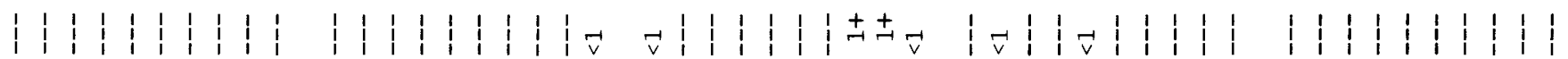

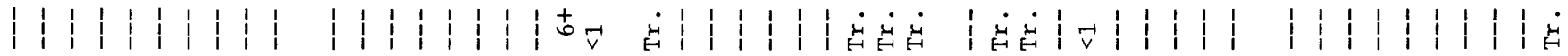

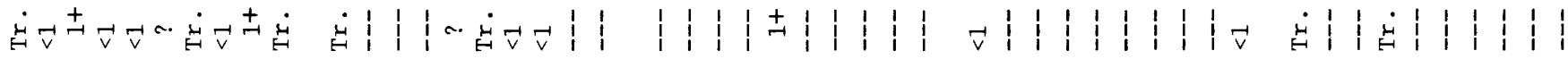

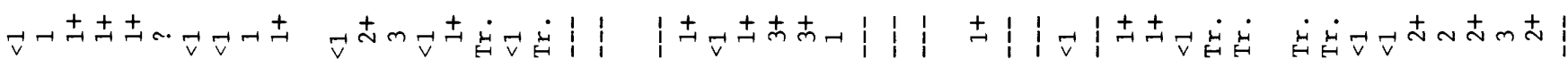

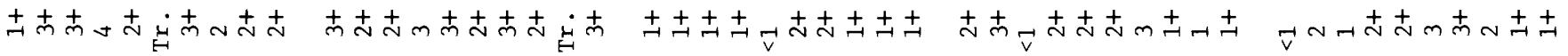
|

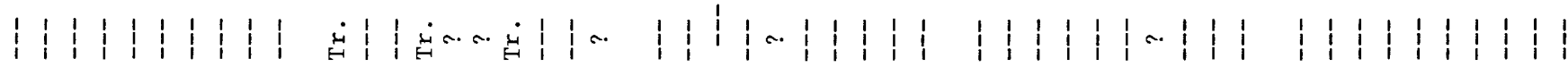

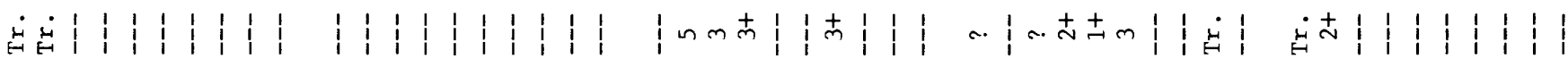

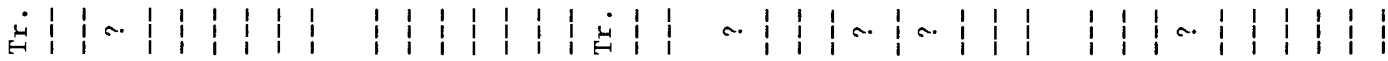

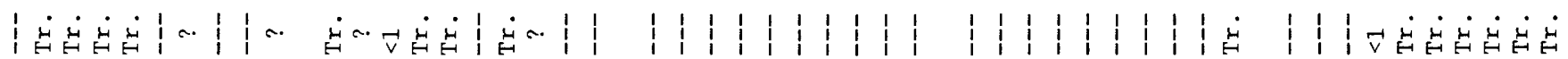

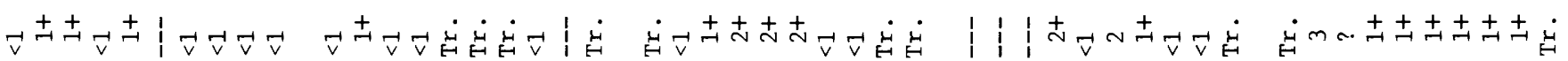

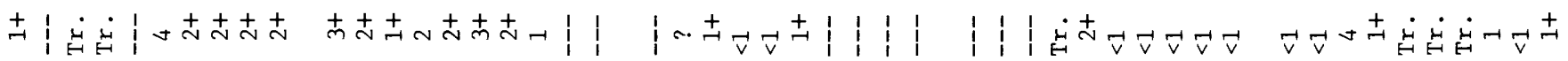

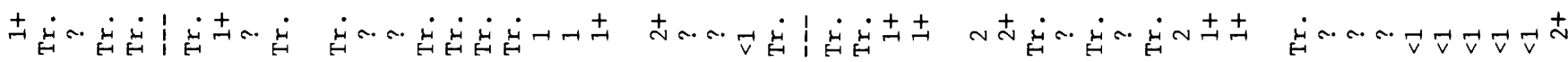

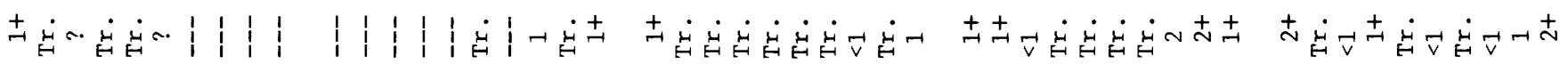

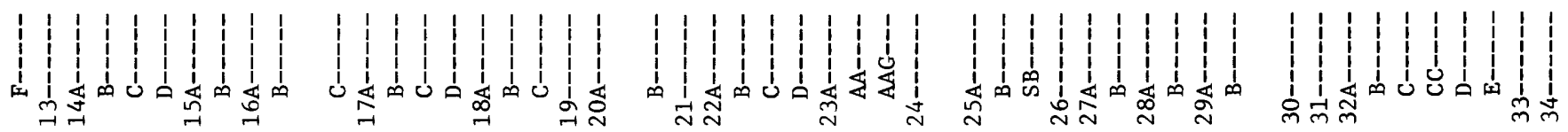




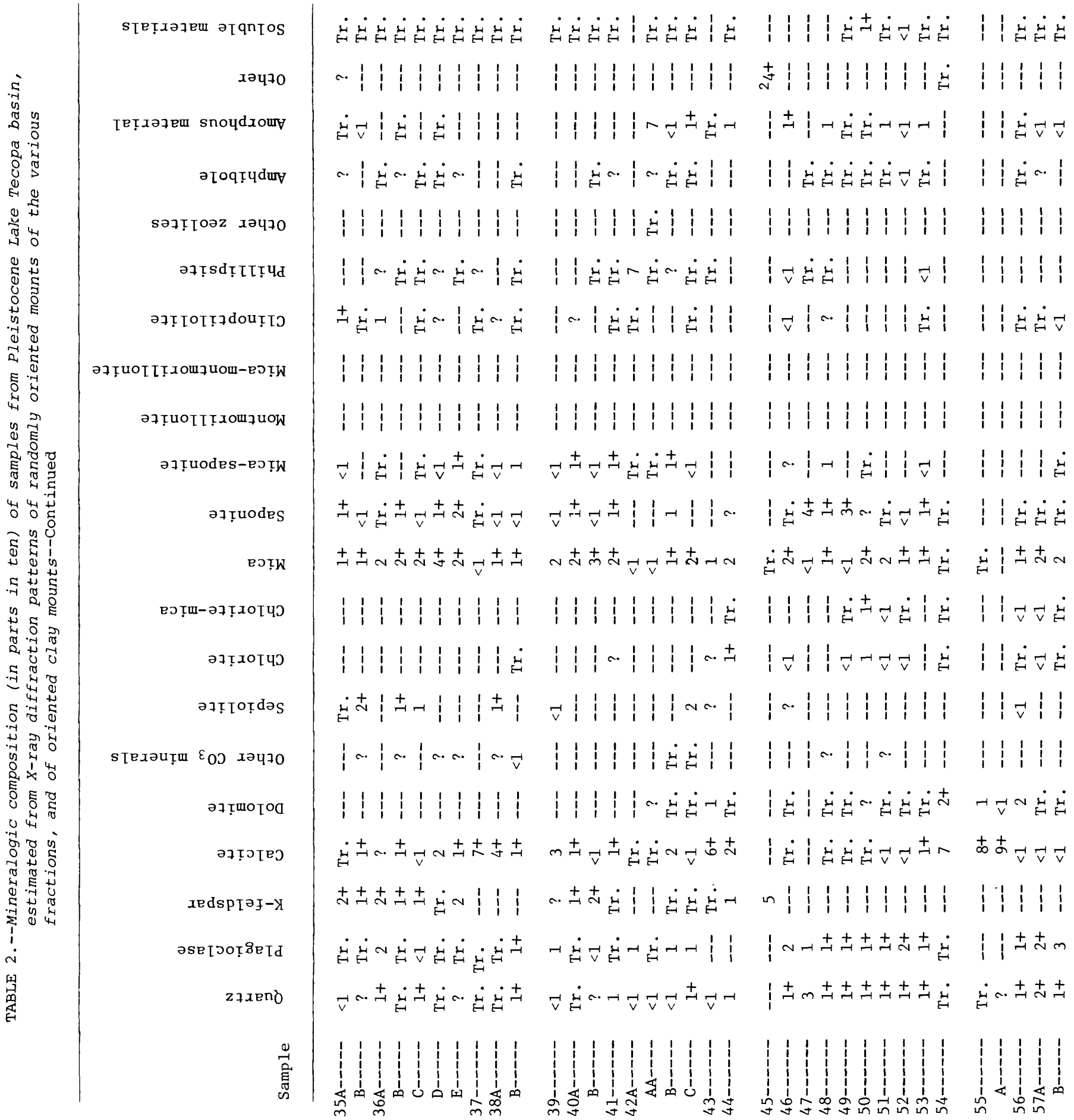




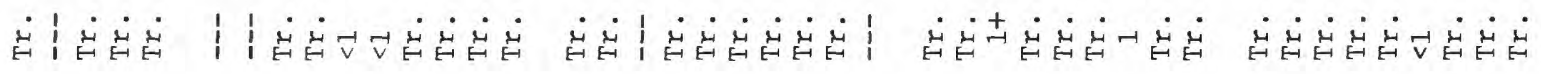

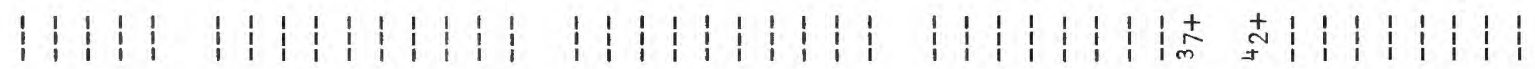
岳

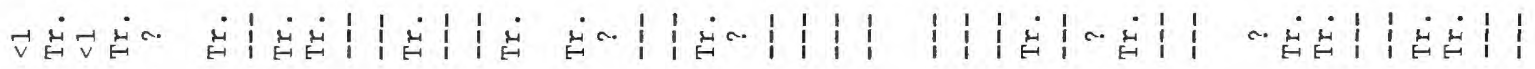

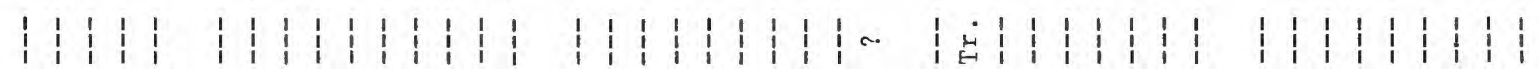

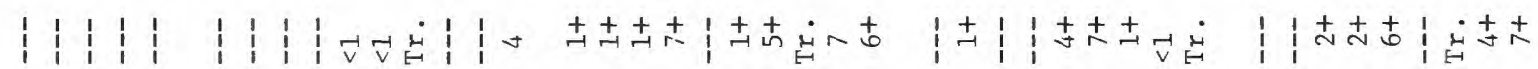

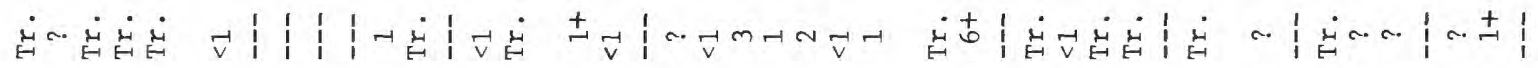

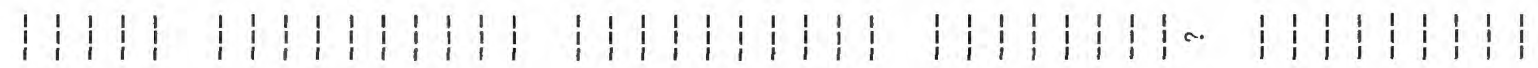

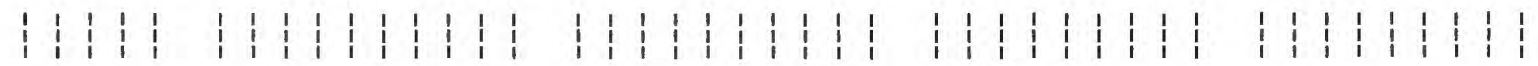

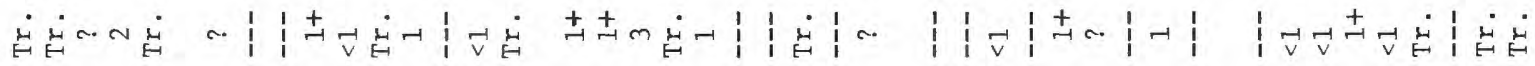

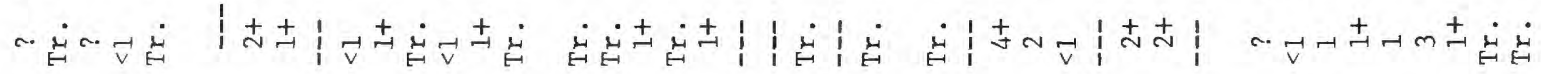

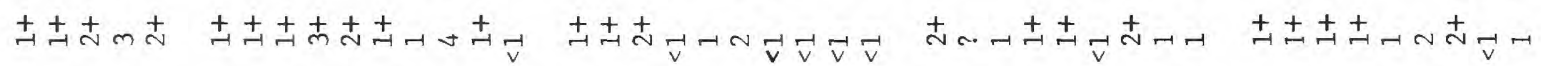

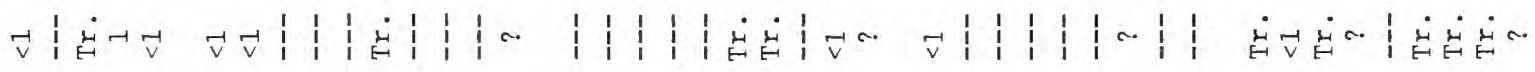

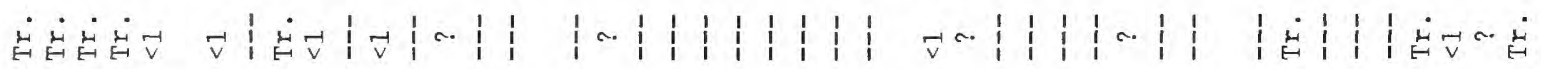

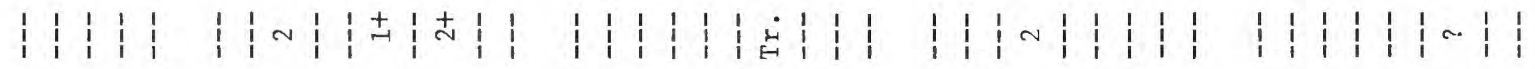
它 จ

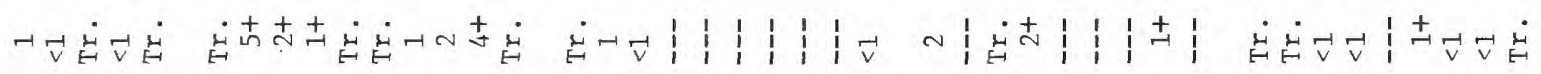

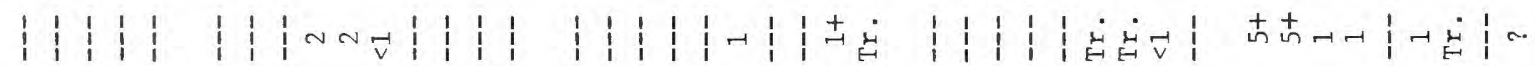

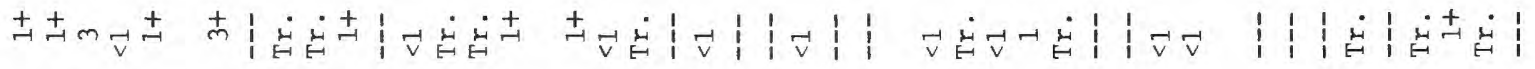

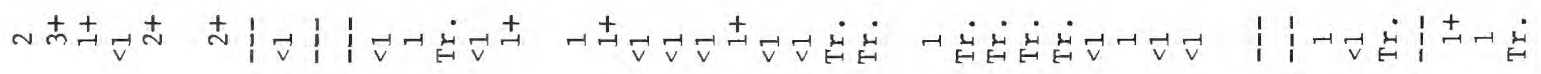

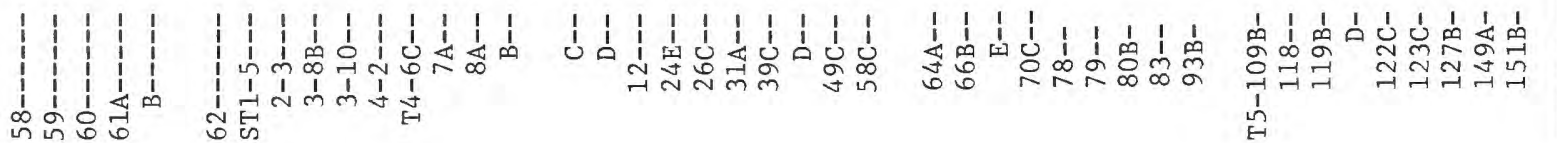




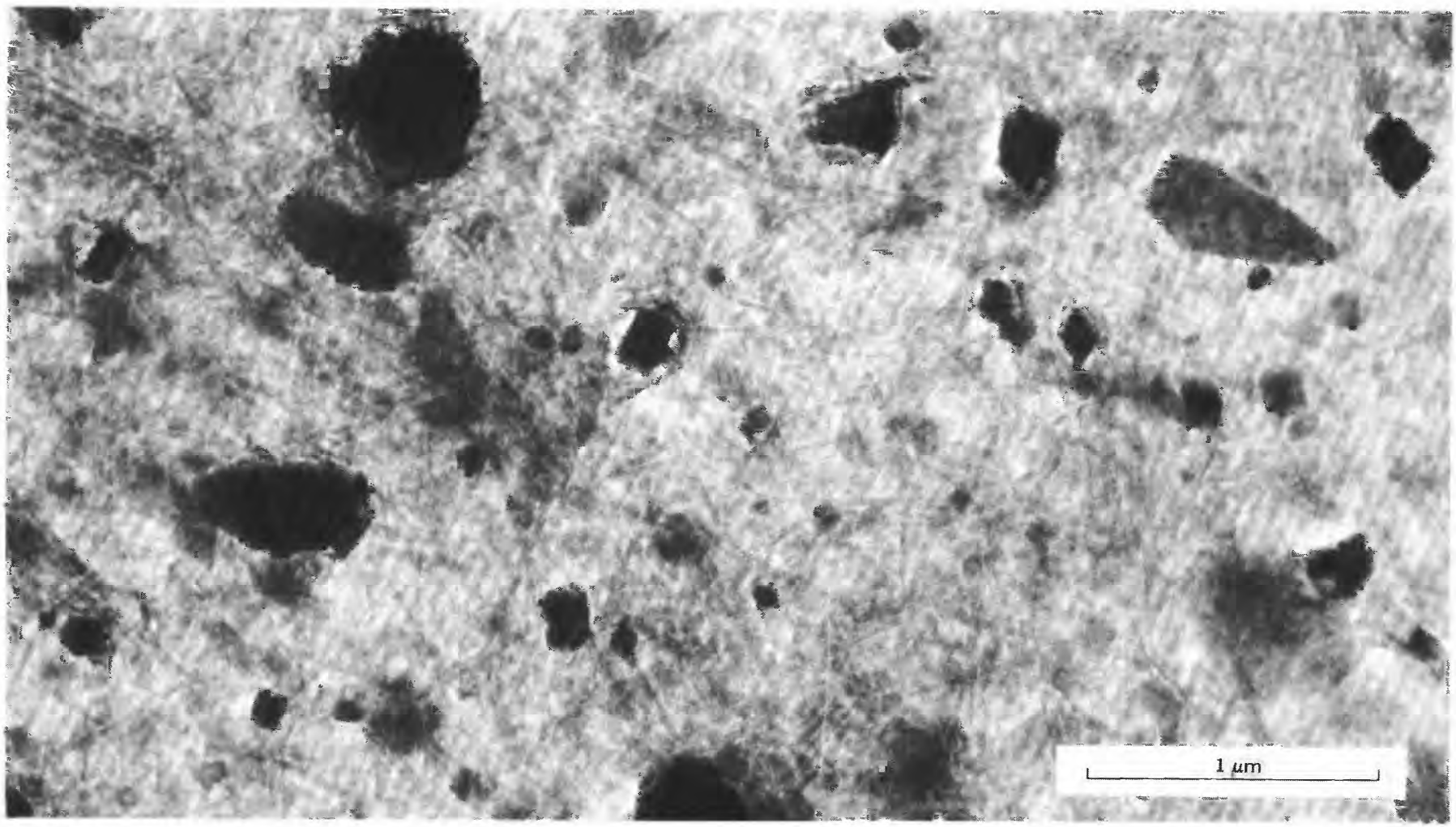

FIGURE 6.-Transmission electron micrograph of sample 21 showing suspended sepiolite. Note the presence of rhombohedral calcite crystals.

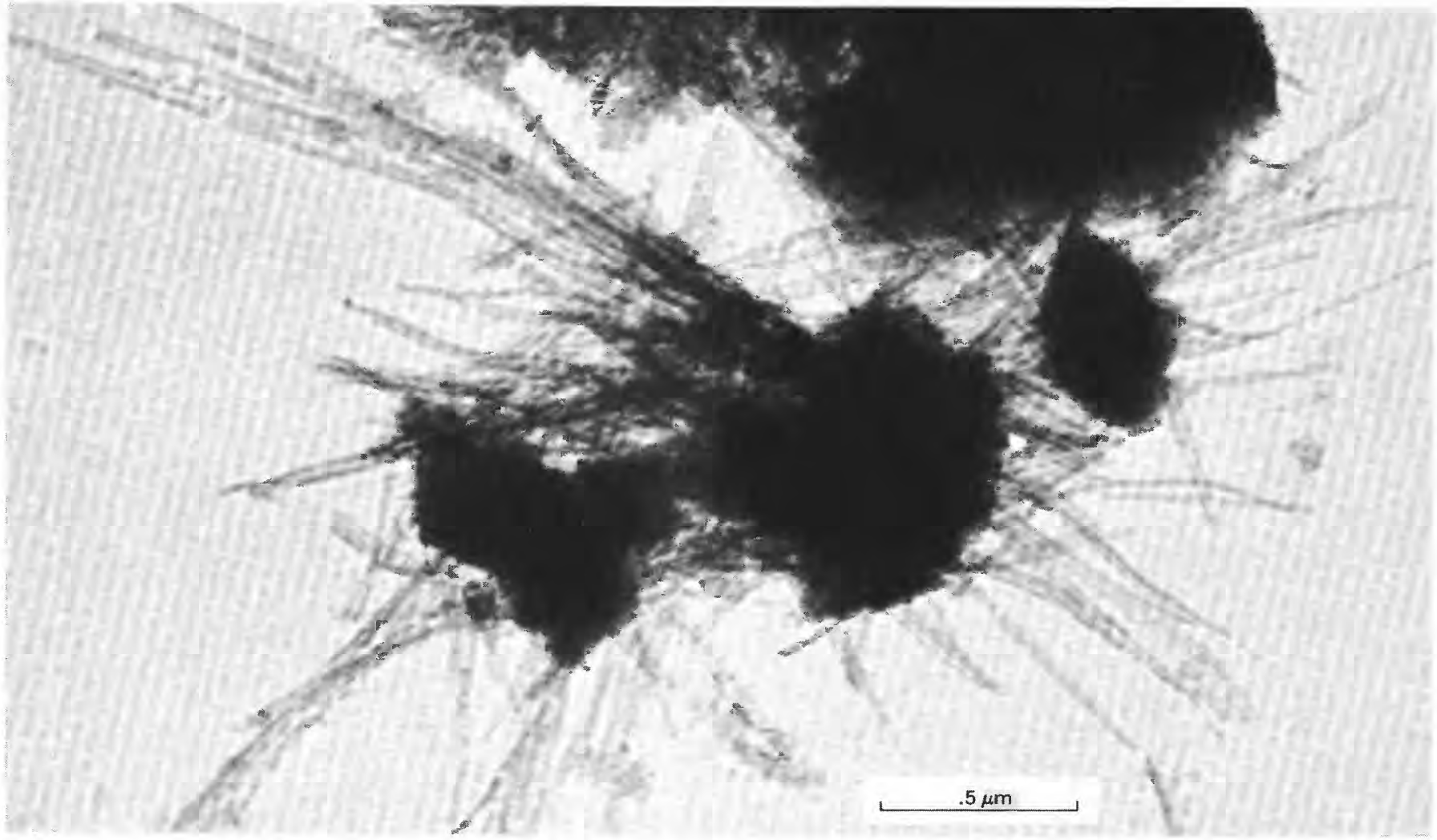

FIGURE 7.-Transmission electron micrograph of sample 1A showing suspended sepiolite fibers more than 2 micrometers long. 


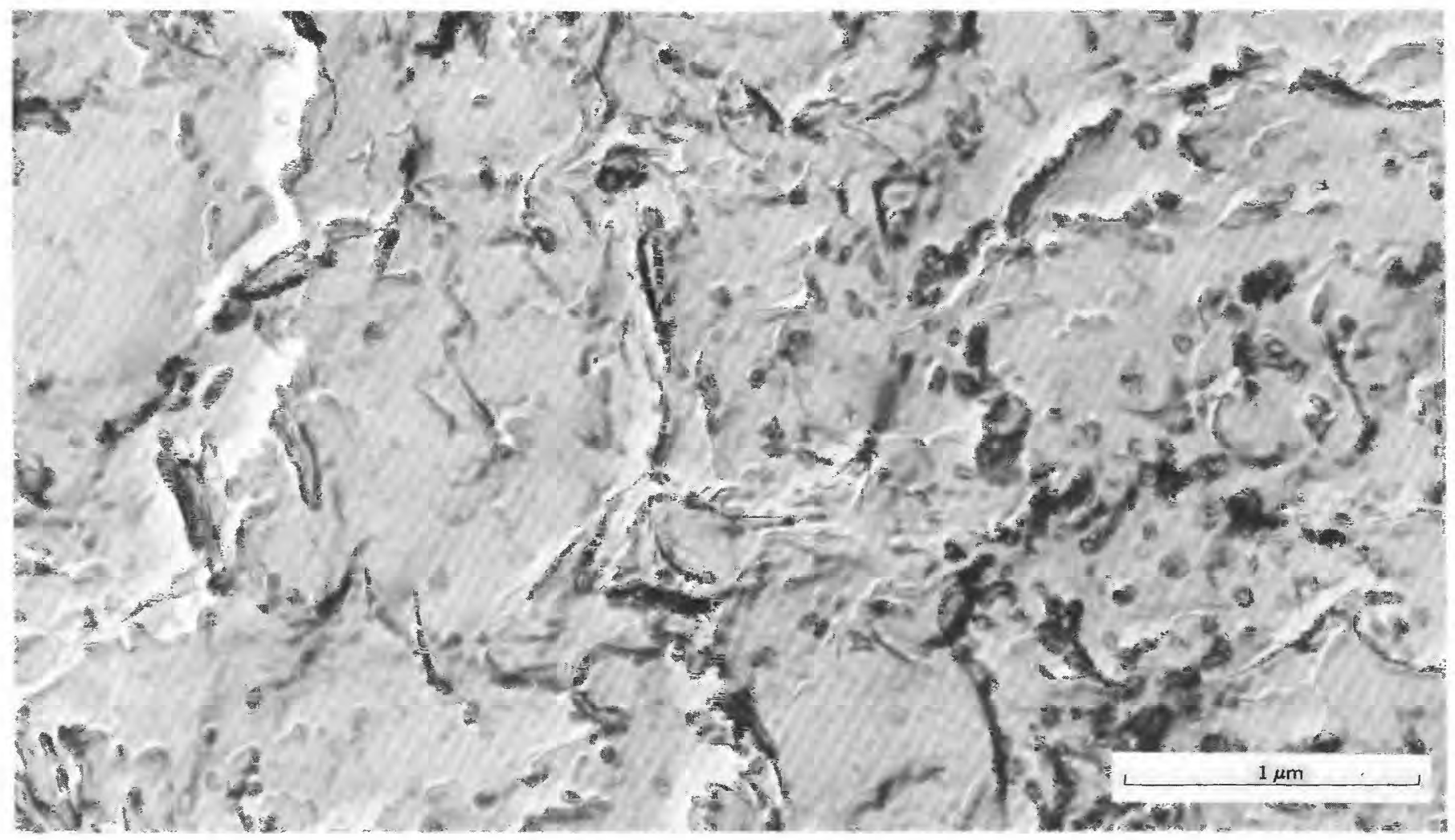

FIGURE 8.-Transmission electron micrograph of sample 12B, surface replica of sepiolite, showing some of the fibrous bundles protruding from the surface.

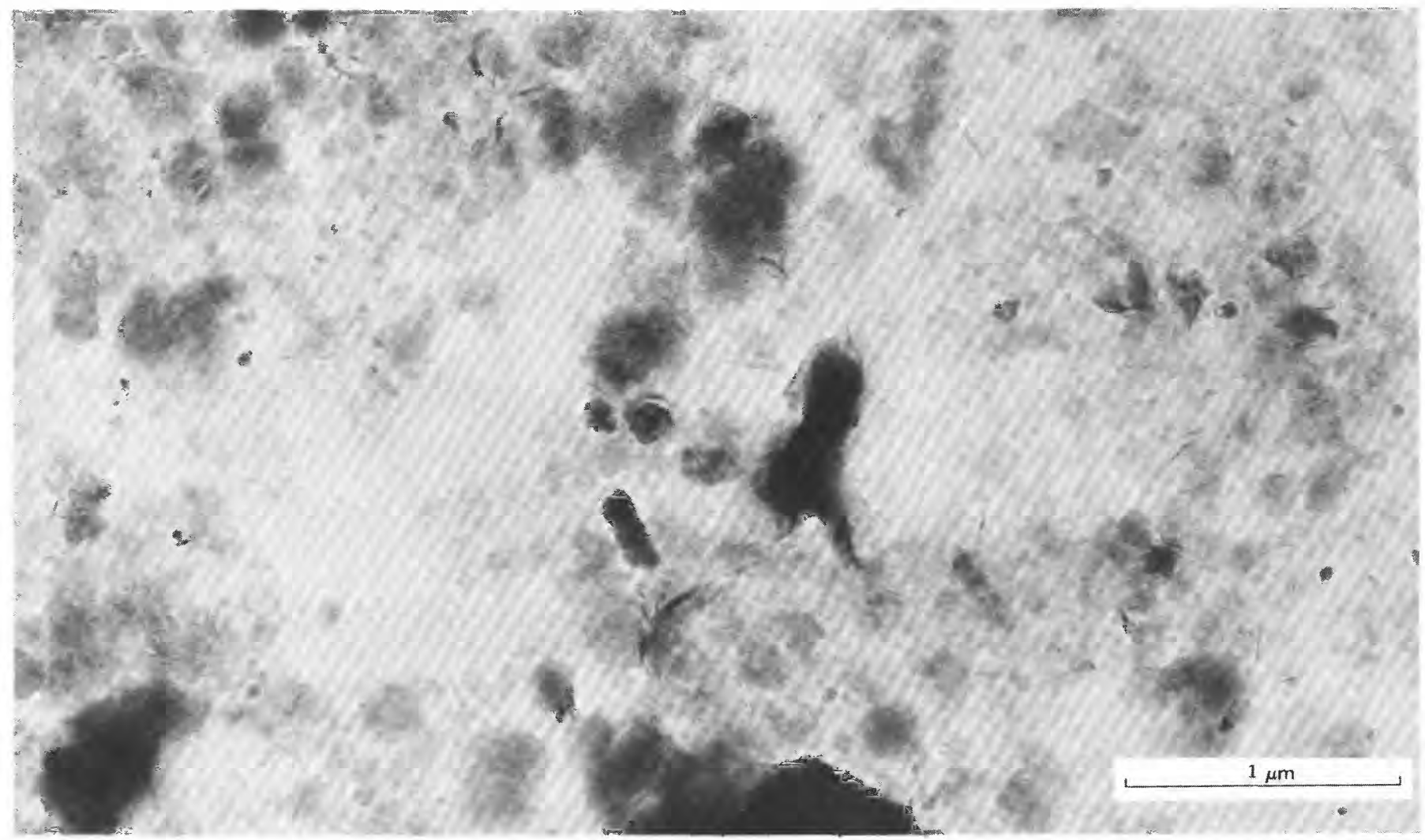

FIGURE 9.-Transmission electron micrograph of suspended saponite. Note the very short fibers of saponite. 
farther down in the column higher amounts are again found.

Sediments sampled near the center of the basin and stratigraphically below the intermediate tuff contain little or no quartz. Some samples taken at the same levels, but near the Chicago Valley junction at the edge of the basin, contain some quartz but the amounts are small.

Some cyclical variation in quartz content throughout the stratigraphic column is suggested, but sampling was insufficient to prove this. Changes in source and (or) volume of the incoming sediments could easily account for stratigraphic variations in the quantity of quartz and changes in lake-water chemistry, perhaps due to rainfall fluctuations, may also have had some influence. During periods of fresh-water incursions the $\mathrm{pH}$ of the lake waters would have been lowered producing conditions in which the quartz would have been more stable. Conversely, during dry periods evaporation of the lake waters would have caused an increase in salinity and $\mathrm{pH}$.

Frondel (1962) stated that quartz, especially microcrystalline varieties, is slowly attacked by alkaline solutions at room temperatures. This solubility of quartz may account for the lack of it in the older and central part of the lake sediments where it would have been subjected to attack by the alkaline waters for longer periods of time than was the quartz of the more recently deposited sediments or the quartz that was located around the basin edge where the alkalinity of the lake waters would have been diluted by runoff.

The feldspars observed in this suite of samples consisted of potassium feldspar of probable authigenic origin and detrital plagioclase. The plagioclase was found as a minor constituent in most samples of the mudstones. It was found in very small quantities, or not at all, in samples of the tuff. Samples collected from along the streambeds north of the lake (fig. 2), especially from the bed of the Amargosa River, contained more plagioclase feldspar than did any of the other samples. A fairly high plagioclase content was also found in the Chicago and Greenwater Valley drainages and near their points of entry into the Tecopa basin.

\section{POTASSIUM FELDSPAR}

The potassium feldspar, determined to be authigenic by Sheppard and Gude (1968), was found mostly in the central part of the basin, especially in or near the tuffs, and was almost completely absent from the samples taken outside the basin except at locality 45 . At locality 45 , a rock sample with a gray and red laminated appearance proved to be half potassium feldspar, almost half cristobalite, and a trace of mica. The greatest concentration of the potassium feldspar was found in the west-central part of the lake basin below tuff B-within the area designated by Sheppard and Gude as the potassium feldspar zone.

\section{CARBONATES}

Calcite is found throughout the lake beds, and outside the former lake boundaries. However, some samples taken just within the boundaries of the lake showed little or no calcite. Most of these samples were taken near the entrance of present intermittent streams or close to the mountains where runoff from storms would most likely have been heavy. The area where Greenwater Valley enters the Lake Tecopa basin, and where runoff is likely to be heavy at times, also contains little calcite. The largest amounts of calcite were found at the northern end of the valley where the Amargosa River flowed into the lake. In that area the fresh waters of the river, bearing calcium which had been taken into solution from the larger drainage area upstream, mixed with the carbonate-rich lake brines of high $\mathrm{pH}$ and precipitated calcite.

Dolomite is found most extensively as detritus at the edges of the basin but small amounts occur in the mudstones within the basin. The amounts of dolomite are less than 10 percent and usually only a trace. In general, dolomite is not found in a sample with sepiolite although there are some minor exceptions. Sheppard and Gude (1968) have recognized several thin beds of finely crystalline dolomite in the Lake Tecopa basin deposits.

Jones (1961), on the basis of the pattern of distribution of the dolomite in the Deep Spring Lake playa in California, attributed the formation of the dolomite to direct precipitation from solutions. Peterson, Bien, and Berner (1963) concluded from radiocarbon dating studies that the dolomite in Deep Spring Lake was precipitated directly from solution with no intermediate calcite phase. They stated that very slow crystal growth (on the order of hundreds of Angstroms per thousand years) seems necessary to form dolomite. Clayton, Jones, and Berner (1968), basing their results on X-ray diffraction, solubility, and isotopic measurements, concluded that the fine-grained dolomite in Deep Spring Lake was formed by direct precipitation from solution, although they did not rule out the possibility that detrital or authigenic calcite in the lake could have been transformed into colomite.

The amount of dolomite in the Lake Tecopa area is not sufficient to draw conclusions from the distribution as to its origin as did Jones (1961), and the scope of the present paper precludes the use of more 
sophisticated techniques necessary to determine the origin of the dolomite. If the dolomite in Lake Tecopa was precipitated at the same rate as that described by Peterson, Bien, and Berner (1963) in Deep Spring Lake, the size of the largest dolomite crystals based on the age of the lake should be approximately 0.1 micrometers. At least some of the dolomite was found in the sand- and silt-sized fractions, which indicates that perhaps some of the dolomite in Lake Tecopa is detrital, or was formed by the magnesium replacement of calcium in some of the calcite. Part of the finegrained dolomite in the clay-sized fraction could have been precipitated directly from the alkaline lake waters. Probably the thin dolomite beds reported by Sheppard and Gude (1968) were authigenic in origin.

Minor amounts of other carbonate minerals were also found. A probable identification was made of a trace of siderite in a couple of samples, and aragonite was identified in the sample from site 54 . Manganocalcite and rhodochrosite were found in less than 20 percent of the samples, usually in trace amounts. They were found not only in the mudstones of the basin but in the detritus along the Amargosa River upstream from the basin and in Chicago Valley to the east. These occurrences would indicate that these minerals are detrital but it is possible that some of them that were found in the mudstones were precipitated from solution.

\section{MAGADIITE}

Magadiite was first described by Eugster (1967), who reported its occurrence at Lake Magadi, Kenya, in the High Magadi beds of Late Pleistocene to Holocene age. He, and later Jones, Rettig, and Eugster (1967), stated that the magadiite was precipitated from alkaline, silica-rich brines of high $\mathrm{pH}$ in waters of a more dilute precursor of present-day Lake Magadi. According to Eugster (1969), if such brines come in contact with fresh water, a stratification of the lake may occur producing magadiite saturation at the interface. Solubility curves for magadiite (Eugster, 1969) sug. gest a minimum $\mathrm{pH}$ value of between 8.5 and 9.0, which may be the lower limit of $\mathrm{pH}$ for precipitation of magadiite. Bricker (1969) stated that above $\mathrm{pH} \mathrm{9,}$ magadiite would be soluble because of the increased silica solubility, and below $\mathrm{pH} 9$, its solubility would be increased owing to decreasing $\left[\mathrm{Na}^{+}\right] /\left[\mathrm{H}^{+}\right]$ratio.

The mineral has since been reported from two localities in the United States: Trinity County, Calif. (McAtee and others, 1968), and Alkali Lake, Oreg. (Rooney and others, 1969). Magadiite is reported in Lake Tecopa as the third occurrence in the United States. The sample, T4-93, containing the magadiite was one of those furnished to the authors by Sheppard and Gude, who stated (Oral Commun., 1975) that the deposit is small, probably not exceeding a couple of cubic yards, including the impurities associated with it which make up about one-fourth of the sample. The sample locality was on the main "island" in the southern part of the basin just north of Tecopa; the deposit was not connected to the other clay beds. The elevation of the magadiite was estimated to be about $488 \mathrm{~m}$, stratigraphically about the level of tuff A.

The X-ray powder diffraction data from the Lake Tecopa sample are compared with those of the Trinity County, Alkali Lake, and Lake Magadi samples in table 3 and show very good agreement. Comparison of electron micrographs (figs. 10,11) of the Lake Tecopa magadiite and the Trinity County magadiite show the Trinity County material to be made up of crystals about 2-2 $1 / 2$ times the size of the Lake Tecopa crystals. Whereas the Trinity County crystals are square or rectangular, the Lake Tecopa crystals appear to be broken and irregular and mixed with other detrital minerals commonly found in the mudstones of the basin.

The precipitation of magadiite in Lake Tecopa is somewhat analogous to that of the sepiolite, as described in the section on sepiolite. Apparently the tuff supplied the silica to the water which was disseminated into the surrounding detrital beds where it came into contact with their high $\mathrm{pH}$ (about 9.0 or more) high-sodium pore waters. Bricker (1969) has stated that under these conditions, but in the absence of reactive aluminous phases, magadiite could precipitate when an incursion of fresh water dropped the $\mathrm{pH}$ to about 9.0 and the $\left[\mathrm{Na}^{+}\right] /\left[\mathrm{H}^{+}\right]$ratio was at least 5. Any reactive alumina made available in the dissolution of the tuff would have been used to form the zeolites found in the tuffs or at the interface of the tuffs with the detrital beds.

If the Tecopa magadiite was precipitated in the manner described by Eugster (1967) for the waters of Lake Magadi, then the mineral may have covered a larger area in the Lake Tecopa basin than is apparent from the present-day deposit. Subsequent erosion that has scoured the clay beds and tuffs would have removed most of the magadiite, or the sodium could have been leached out leaving behind silica which converted to microcrystalline quartz (Eugster, 1969) or opaline silica.

However, it is probable that one or more sodium-rich springs existed on or near the "island" where the magadiite is found. Chemical analyses of the spring waters in various localities throughout the basin show that the sodium content of the springs of the nearby town of Tecopa is higher than that of any of the others. 
TABLE 3.--X-ray diffraction data for magadiite

\begin{tabular}{|c|c|c|c|c|c|c|}
\hline \multicolumn{2}{|c|}{ [Leaders } & \multicolumn{3}{|c|}{$(--)$, not found or not } & reporte & \\
\hline \multicolumn{2}{|c|}{$\begin{array}{c}\text { Lake Tecopa, } \\
\text { Calif. }\end{array}$} & \multicolumn{2}{|c|}{$\begin{array}{l}\text { Lake Magadi, } \\
\text { Kenyal }\end{array}$} & \multirow{2}{*}{$\frac{\begin{array}{c}\text { Trinity, } \\
\text { Calif. }\end{array}}{\mathrm{d}}$} & \multicolumn{2}{|c|}{$\begin{array}{c}\text { Alkali Lake, } \\
\text { Oreg. }{ }^{3}\end{array}$} \\
\hline$d$ & $\mathrm{I} / \mathrm{I}_{1}$ & $d$ & $I / I_{1}$ & & $d$ & $\mathrm{I} / \mathrm{I}_{1}$ \\
\hline 15.49 & 100 & 15.41 & 100 & 15.77 & 15.80 & 100 \\
\hline 7.82 & 10 & 7.775 & 9 & 7.79 & 7.82 & 26 \\
\hline--- & -- & $----\infty$ & -- & 7.19 & 7.25 & 10 \\
\hline---- & --- & ----- & --- & 6.88 & ---- & -- \\
\hline 5.57 & 6 & 5.612 & 4 & 5.62 & 5.68 & 10 \\
\hline 5.18 & 16 & 5.181 & 19 & 5.18 & 5.21 & 26 \\
\hline 5.01 & 18 & 5.007 & 16 & 5.01 & 5.03 & 21 \\
\hline---- & -- & ----- & --- & 4.69 & --- & -- \\
\hline 4.46 & 25 & 4.464 & 18 & 4.46 & 4.48 & 24 \\
\hline 4.00 & 19 & 4.008 & 9 & 4.00 & 4.00 & 17 \\
\hline 3.90 & 8 & 3.909 & 4 & 3.93 & --- & --- \\
\hline 3.63 & 15 & ---- & --- & 3.62 & 3.62 & 26 \\
\hline 3.55 & 25 & 3.543 & 12 & 3.54 & 3.53 & 25 \\
\hline 3.43 & 85 & 3.435 & 80 & 3.43 & 3.44 & 74 \\
\hline 3.31 & 70 & 3.296 & 35 & 3.30 & 3.30 & 53 \\
\hline 3.19 & 55 & 3.200 & 10 & 3.20 & $-\cdots$ & -- \\
\hline 3.14 & 65 & 3.146 & 50 & 3.14 & 3.14 & 57 \\
\hline 2.99 & 8 & 2.994 & 3 & 2.99 & ---- & --- \\
\hline
\end{tabular}

\footnotetext{
lEugster (1967).

2McAtee and others (1968).

${ }^{3}$ Rooney and others (1969).
}

This higher sodium content could have been sufficient to form magadiite at this location, all other factors being present. In other areas possibly the $\left[\mathrm{Na}^{+}\right] /\left[\mathrm{H}^{+}\right]$ ratio was not high enough to precipitate magadiite because of the prevalence of magnesium and other cations.

\section{ZEOLITES AND AMORPHOUS MATERIAL}

The principal zeolites found in the clay formations are clinoptilolite and phillipsite, with the phillipsite being found most often in the samples containing significant amounts of potassium feldspar. Although zeolites in small amounts may be found in almost any part of the study area, the greatest concentrations are found in or near the tuffs where they were formed. Sheppard and Gude (1968) made a thorough study of the formation of zeolites in this area and the reader is referred to their work for a discussion of their origin. Other zeolites found in small quantities are erionite and analcime.

No attempt was made to identify the exact composition of the amorphous material although it probably is volcanic ash in various stages of devitrification. Opal, opaline silica, tridymite, and cristobalite were identified, which demonstrates that uncombined silica is abundant in the area. When the sum of the various mineral constituents of a sample was less than 100 percent the presence of amorphous material was suspected, whether or not it was indicated by the typical broad flourescent hump seen between $15^{\circ}$ and $30^{\circ} 2 \theta$ on X-ray diffractometer patterns. Optical examination revealing glass shards was accepted as proof of the presence of amorphous material. Only when the amount of amorphous material was estimated to be 2 parts in 10 or more was the sodium hydroxide leaching technique employed to confirm the amount present.

\section{SALINE MINERALS}

No specific effort was made to sample for saline minerals except at locality 29 in the present-day playa. However, a salty taste was noted in some samples; a salt crust and occasional specks and streaks of gypsum were observed also in some samples. Saline minerals were found to some extent in all but a dozen samples. The amounts varied from a trace to almost 50 percent. The largest quantities were found on the western side of the lake at localities $8,14,15$, and 16 , and at the playa locality, site 29 .

Most of the saline minerals were soluble enough to be leached out of the samples during the fractionation procedures. Some of the gypsum, however, was not entirely removed during these procedures and was converted to bassanite when the fractions were oven-dried at $110^{\circ} \mathrm{C}$.

Halite is the predominant evaporite; next in abundance is gypsum. Traces of thenardite and gaylussite were found infrequently. Only one sample contained a trace of soda nitre, even though, at one time, there were several nitrate claims in the area (Noble, Mansfield, and others, 1922).

Because Pleistocene Lake Tecopa is no longer a closed basin, but has been drained and eroded, it is unlikely that the present-day saline minerals would approach the composition of the salts present at the time of the formation of the authigenic minerals. Rather, they would reflect modern conditions.

\section{OTHER MINERALS}

There were a few nonclay minerals in the mudstones which were so widely scattered or present in such small amounts that they will be listed here together although there may be no relationship among them. The most widespread of these minerals were the amphiboles which usually are present only in trace amounts in any particular location. Only one or two of 


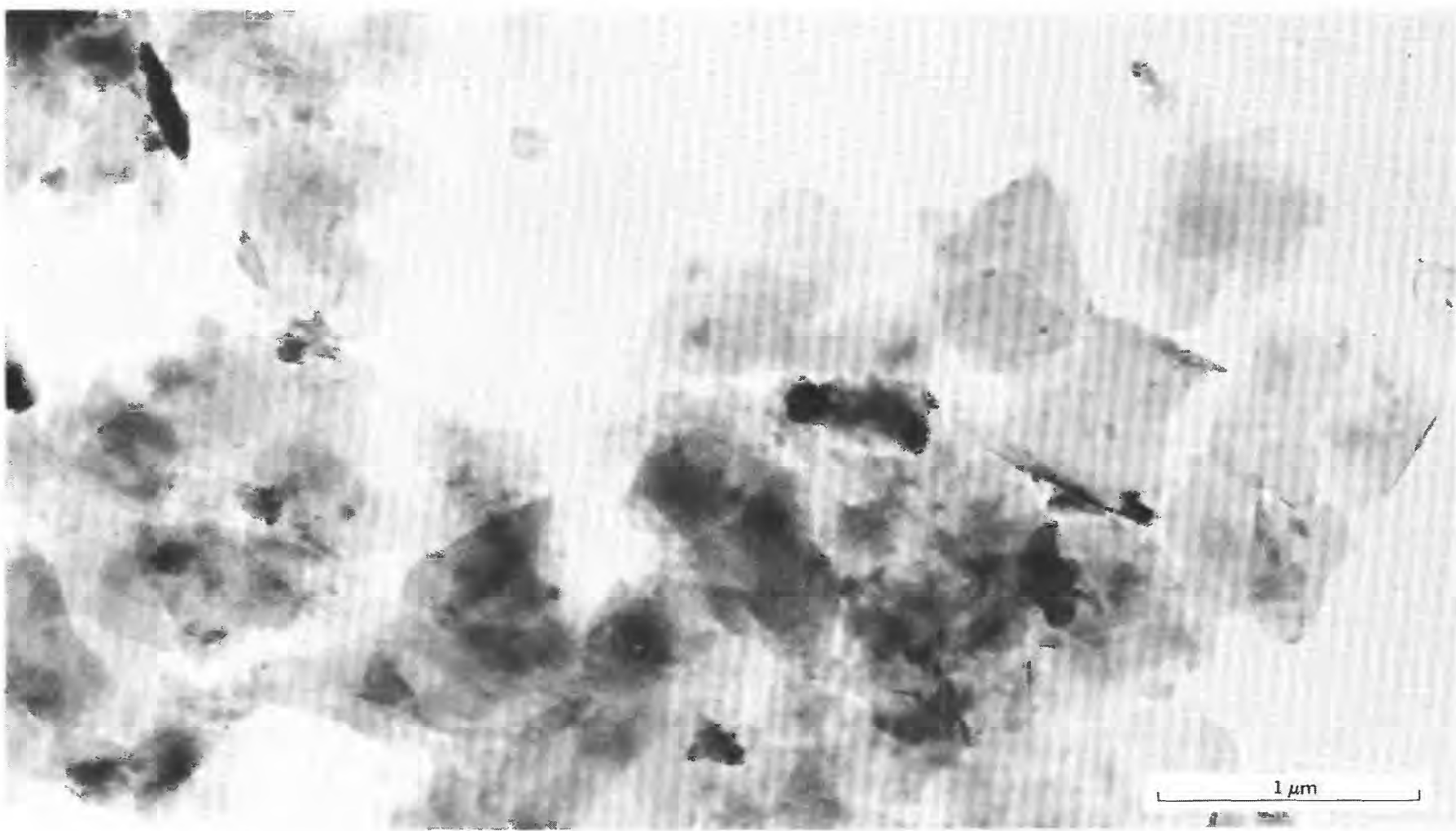

Figure 10.-Transmission electron micrograph of sample T-93; suspended crystals of magadiite, Pleistocene Lake Tecopa basin.

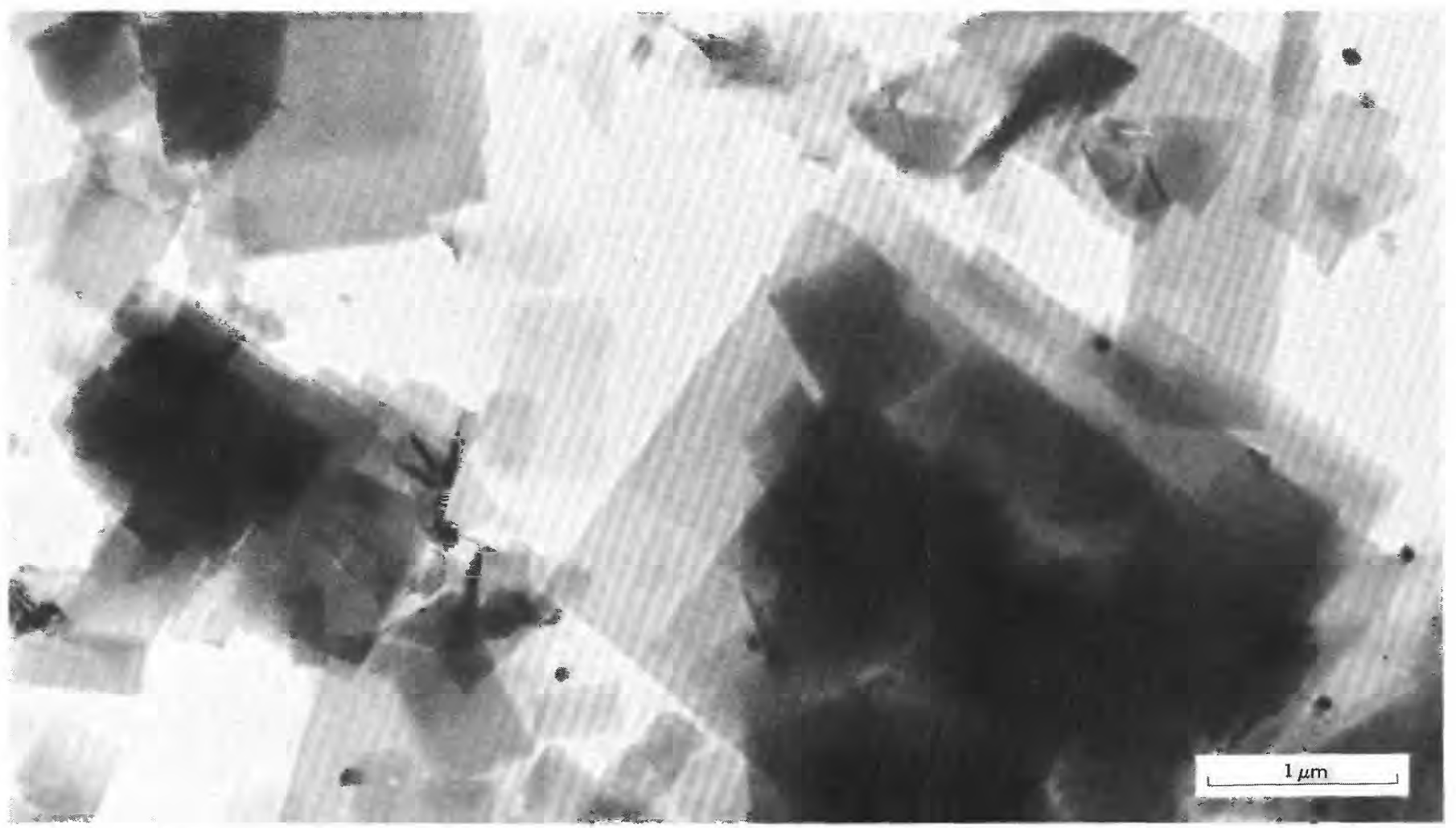

FIGURE 11.-Transmission electron micrograph of suspended crystals of magadiite from Trinity County, Calif. 
the identifiable, diagnostic, amphibole peaks were visible on the X-ray diffractometer charts because the amounts of the minerals were so small, and therefore the type of amphibole usually was not determined. The only identified species of amphibole was tremolite.

Searlesite was inconclusively identified in 10 samples, most of which were located in the west side of the lake beds. In one or two samples, only tentative identification was made of pyrite, magnetite, and anhydrite because of the small amounts present. No conclusions could be drawn about them.

\section{CLAY MINERALS}

The amounts of nonclay minerals were subtracted from the total mineral content, and the remaining clay mineral content was recalculated to 100 percent. From these data the stratigraphic distribution of clay minerals was plotted (fig. 12). In this diagram certain relationships become apparent. Sepiolite is found, with few exceptions, close to the tuffs. Montmorillonite, when present, is also found close to the tuffs. Mica, illite, saponite, and mixed-layer clays are found at almost all stratigraphic levels. The reasons for these distributions will become apparent in the discussions of the individual minerals.

Data from representative X-ray diffraction patterns of randomly oriented mounts of saponite and sepiolite are shown in table 4. Frequently clay minerals in saline sediments are poorly crystallized (Grim, 1968); this is especially true of the authigenic minerals. This poor crystallinity, noted in most of our samples, together with small particle size which made it impossible to obtain pure samples accounts for the fact that some smaller reflections, usually found on X-ray diffraction patterns, are missing from these data.

\section{CHLORITE AND CHLORITE-MICA}

Chlorite and mixed-layered chlorite-mica are found in the stream beds outside the margins of the lake and, to a lesser extent, in the basin areas close to the mouths of the incoming streams. There is very little chlorite in the central or southern parts of the basin except close to the Amargosa River.

Where the amount of chlorite or chlorite-mica is given as “?", the identification is based on the presence of a small diffraction peak appearing at $14^{\circ}$ $2 \theta$ for chlorite or to one appearing between $10^{\circ}$ and $14^{\circ}$ $2 \theta$ for chlorite-mica. Because of the small amounts present these peaks are not seen on heating to $400^{\circ} \mathrm{C}$ or on glycolation; neither are the higher order reflections
TABLE 4.--Comparison of $X$-ray diffraction spacings of sepiolite and saponite from Pleistocene Lake Tecopa with previously reported occurrences

[Leaders (--), not found or not reported]

\begin{tabular}{|c|c|c|c|c|c|c|c|}
\hline \multicolumn{4}{|c|}{ Sepiolite } & \multicolumn{4}{|c|}{ Saponite } \\
\hline \multicolumn{2}{|c|}{$\begin{array}{c}\text { Lake Tecopa, } \\
\text { Calif. }\end{array}$} & \multicolumn{2}{|c|}{$\begin{array}{c}\text { Apandandrava, } \\
\text { Indial }\end{array}$} & \multicolumn{2}{|c|}{$\begin{array}{c}\text { Lake Tecopa, } \\
\text { Calif. }\end{array}$} & \multicolumn{2}{|c|}{$\begin{array}{l}\text { Milford, } \\
\text { Utah }^{2}\end{array}$} \\
\hline d & $\mathrm{I} / \mathrm{I}_{1}$ & ${ }^{3} \mathrm{~d}$ & $\mathrm{I} / \mathrm{I}_{1}$ & $d$ & $\mathrm{I} / \mathrm{I}_{1}$ & $d$ & $\mathrm{I} / \mathrm{I}_{1}$ \\
\hline 12.37 & 100 & 12.3 & 100 & 14.5 & 100 & 16.6 & 100 \\
\hline ---- & -- & 7.56 & 8 & ---- & -- & 4.94 & 20 \\
\hline$-\infty-\infty$ & --- & 6.73 & 4 & 4.52 & 50 & 4.51 & 80 \\
\hline---- & --- & 5.05 & 6 & 3.78 & 12 & 3.70 & 40 \\
\hline$-\cdots--$ & -- & 4.81 & $<1$ & 3.67 & 10 & ---- & --- \\
\hline 4.50 & 25 & 4.54 & 14 & 3.21 & 10 & 3.21 & 10 \\
\hline ---- & --- & 4.32 & 13 & ---- & -- & 2.89 & 40 \\
\hline 3.75 & 13 & 3.77 & 14 & 2.59 & 40 & 2.58 & 50 \\
\hline$--\infty$ & --- & 3.55 & 3 & --- & -- & 2.26 & 10 \\
\hline 3.36 & 10 & 3.36 & 15 & ---- & --- & 2.06 & 10 \\
\hline ---- & -- & 3.20 & 8 & 1.71 & 10 & 1.72 & 30 \\
\hline---- & --- & 3.06 & 3 & 1.52 & 30 & 1.52 & 90 \\
\hline$---\infty$ & --- & 2.84 & $2 b$ & ---- & -- & ---- & -- \\
\hline----- & $-\cdots$ & 2.70 & $6 b$ & ---- & --- & ----- & -- \\
\hline---- & -- & 2.63 & 6 & ----- & -- & ----- & -- \\
\hline 2.57 & 25 & 2.57 & 18 & ----- & -- & ----- & -- \\
\hline
\end{tabular}

1Fahey, Ross, and Axelrod (1960).

${ }^{2}$ Cahoon (1954).

${ }^{3}$ Plus 25 more peaks with intensities less than 10 .

seen. Therefore, we recognize the possibility that some of these peaks may be due to chlorite-montmorillonite although this is not likely because montmorillonite itself is present in minor amounts.

\section{MICA AND ILLITE}

Detrital mica or illite is present in all samples except one of the limestone samples taken from the Dublin Hills.

There appears to be no significant stratigraphic variations in the amounts of mica or illite present (fig. 12). The variations shown apparently are due to the dilution effects of the clay minerals. The micas are predominantly biotite, although occasional flakes of muscovite were found. In the sand-sized fraction, most of the micas are well crystallized and easily visible to the naked eye and their $001 \mathrm{X}$-ray diffraction peaks are sharp. In the silt-sized fraction, the mica becomes somewhat illitic with the 001 diffraction peak becoming asymmetrical on the low-angle side; and in the claysized fraction, the micaceous material becomes very illitic and often grades into a mixed-layered combination with saponite or montmorillonite (fig. 13). 


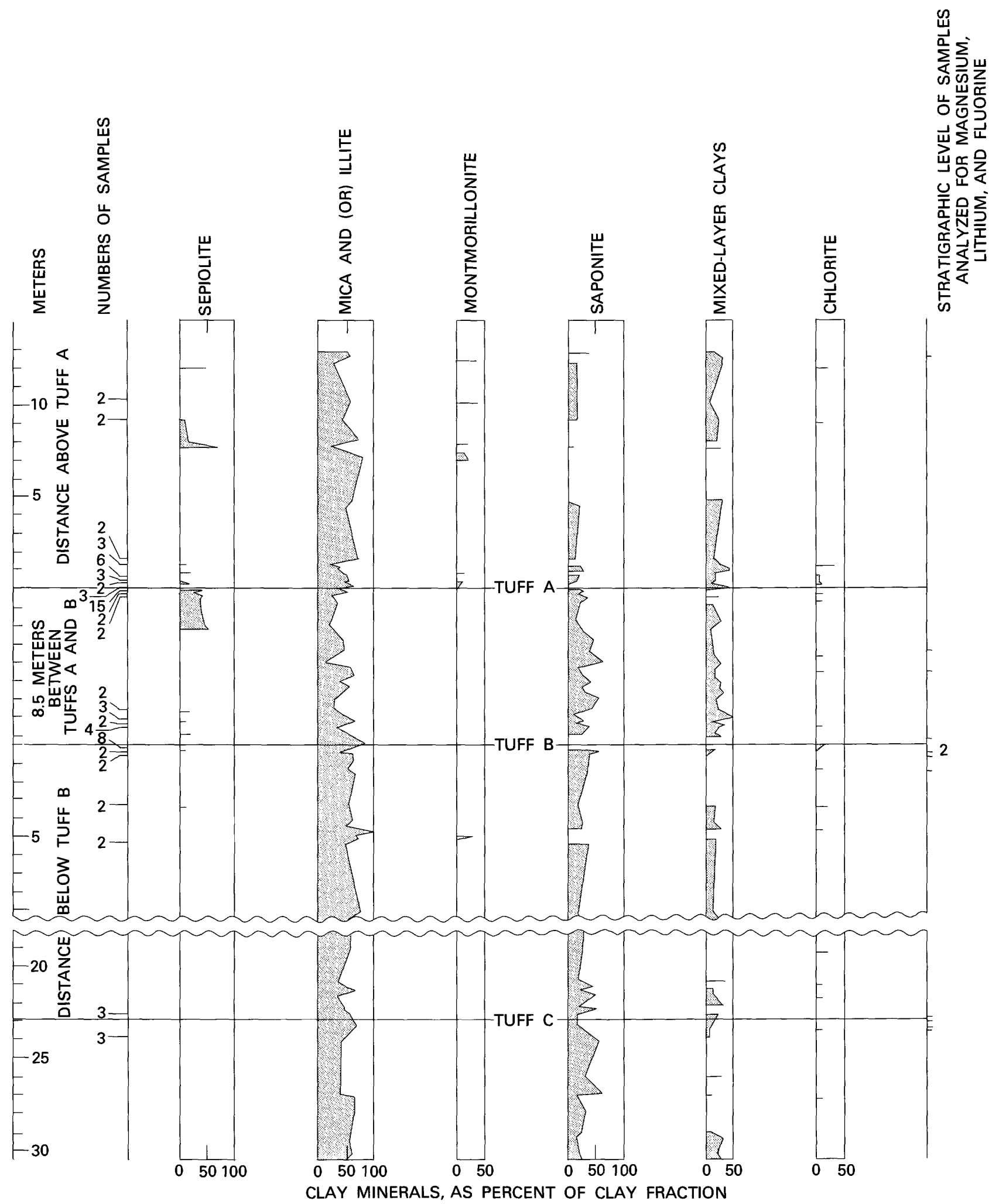

FIGURE 12.-Vertical distribution of clay minerals, in percent. If more than one sample was taken at a given level, the data from the number of samples shown in the second column were averaged. No samples were taken between 9.45 and $18.29 \mathrm{~m}$ below tuff $\mathrm{B}$. 

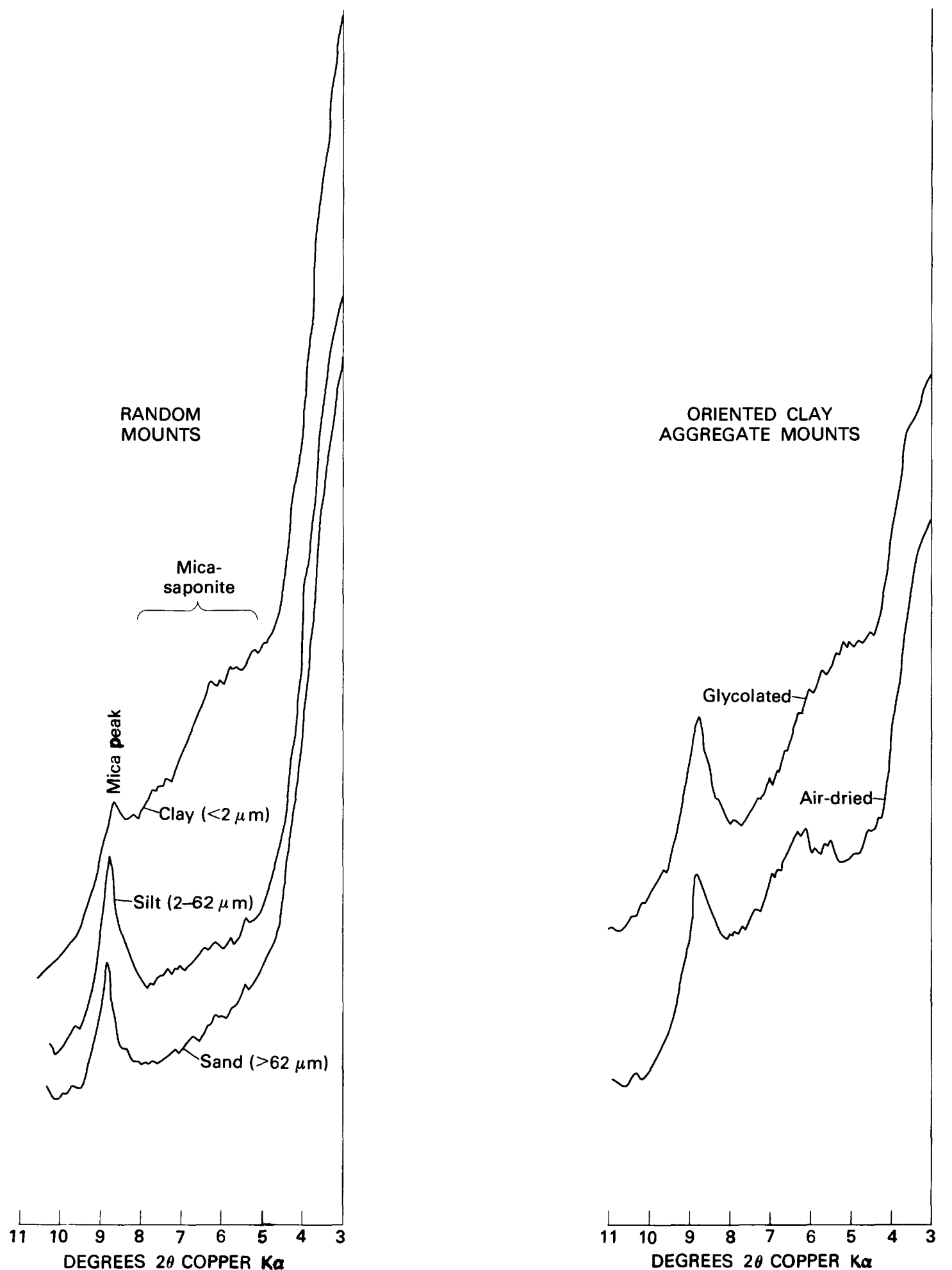

FIGURE 13.-X-ray diffraction curves showing typical gradation from mica to mixed-layer mica-saponite. 


\section{LITHIAN SAPONITE}

The most widespread clay mineral in the area is lithian saponite, which is found not only within the Lake Tecopa basin but also in Chicago Valley and along the Amargosa River upstream.

Electron micrographs (fig. 2) of some of the purified clays from the Lake Tecopa clay beds show a fibrous character. There may be some sepiolite in the sample which was otherwise undetected, but as can be seen in figure 8 , the sepiolite fibers are about twice as long as the fibers in the clay which has been identified as saponite. Saponite, as well as sepiolite, may be fibrous as reported by Midgely and Cross (1956), and Caillère and Hénin (1957). The chemical analysis (table 5) shows that the mineral is high in magnesium, has a little more iron and aluminum than is usual for saponite, and contains lithium. Although the sample was purified as much as possible (no impurities detected by X-ray diffraction) there could be a slight excess of silica due to the amorphous material which is common in the area. The amount of lithium is less than has been reported for hectorite from Hector, Calif. (Ross and Hendricks, 1945; Ames and others, 1958), and the alumina content is greater than in hectorite; therefore, we term this clay a saponite, recognizing the possibility that instead of being a lithian saponite, the clay actually may be a mixture of saponite and hectorite. The position of the 060 diffraction peak near $1.51 \mathrm{~A}$ indicates that almost all the smectite minerals in the Lake Tecopa mudstones are trioctahedral. Lithium, magnesium, and fluorine analyses of 12 samples from various parts of the lake beds (table 6) demonstrate that these elements are present throughout the area. Fluorite was found in none of the samples: small amounts would have been easily detected by X-ray diffraction. Fluorine was not determined in the purified sample because the purified sample was depleted by other analyses.

Lithium in clays has been found in other locations in the arid southwestern part of the United States as reported by Kesler (1960), Norton (1965), and Shawe, Mountjoy, and Duke (1964).

Foshag and Woodford (1936) reported that a clay from $5 \mathrm{~km}$ south of Hector, Calif., was a hydrous magnesium silicate containing appreciable lithia and related to saponite. They stated that similar clays were widespread in the Mojave Desert region of California and Nevada. Strese and Hofmann (1941) named the mineral hectorite.
TABLE 5.--Chemical comparison of Pleistocene Lake Tecopa saponite with other smectites

[Values in percent. Leaders (---), not found; n.d., not determined]

\begin{tabular}{|c|c|c|c|c|}
\hline Sample----- & $\begin{array}{c}\text { Lake } \\
\text { Tecopa, } \\
\text { Calif. } \\
1\end{array}$ & $\begin{array}{c}\text { Hector, } \\
\text { Calif. } \\
2\end{array}$ & $\begin{array}{c}\text { San } \\
\text { Bernadino, } \\
\text { Calif. } \\
3\end{array}$ & $\begin{array}{c}\text { Clay Spur, } \\
\text { Wyo. } \\
4\end{array}$ \\
\hline $\mathrm{SiO}_{2}-\cdots-\cdots$ & 55.82 & 55.86 & 44.00 & 60.96 \\
\hline $\mathrm{Al}_{2} \mathrm{O}_{3}------$ & 4.61 & .13 & 10.60 & 18.27 \\
\hline $\mathrm{Fe}_{2} \mathrm{O}_{3}-\cdots--$ & 2.04 & .03 & Trace & 2.83 \\
\hline FeO-ーーーーーーー & .21 & --- & --- & .14 \\
\hline 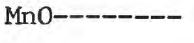 & .04 & None & -- & --- \\
\hline MgO-------- & 21.11 & 25.03 & 24.30 & 2.96 \\
\hline $\mathrm{CaO}--------$ & 1.42 & Trace & 2.00 & .10 \\
\hline $\mathrm{K}_{2} \mathrm{O}--------$ & 1.50 & .10 & --- & .31 \\
\hline $\mathrm{Na}_{2} \mathrm{O}-------$ & .47 & 2.68 & -- & 1.44 \\
\hline $\mathrm{Li}_{2} \mathrm{O}----\cdots$ & .34 & 1.05 & -- & -- \\
\hline $\mathrm{TiO}_{2}$ & .19 & None & --- & .08 \\
\hline F-ー-ーーーーーーー & n.d. & 5.96 & --- & --- \\
\hline $\mathrm{P}_{2} \mathrm{O}_{5}$-ーー-ーー- & .03 & --- & --- & -- \\
\hline $\mathrm{H}_{2} \mathrm{O}+\cdots---$ & 5.76 & 2.24 & 6.20 & 6.56 \\
\hline \multirow[t]{2}{*}{$\mathrm{H}_{2} \mathrm{O}-\cdots$} & 5.26 & 9.90 & 12.60 & 6.78 \\
\hline & 98.80 & 102.98 & 99.70 & 100.43 \\
\hline $0=\mathrm{F}----$ & --- & -2.51 & --- & --- \\
\hline Tota1----- & 98.80 & 100.47 & 99.70 & 100.43 \\
\hline
\end{tabular}

SAMPLE DESCRIPTIONS

1. Lithian saponite, acetic acid-leached clay fraction.

2. Hectorite (Ross and Hendricks, 1945).

3. Saponite (Ross and Hendricks, 1945).

4. Montmorillonite (Kerr and others, 1950).

Ames, Sand, and Goldich (1958) described hectorite as being formed by the alteration of silica tuffs by solutions containing lithium and fluorine in the last stages of hot-spring activity and by lake waters that furnished magnesium. Sand and Ames (1958) said, in their investigation of altered silica volcanics for a source of refractory clay, that saponite is often formed as a result of hot-springs activity where pyroclastics are deposited in alkaline lakes. Their investigation included the Hector, Calif., area.

Later, Sand and Regis (1960), reporting on a lithiumand fluorine-bearing montmorillonite from Tooele County, Utah, questioned whether the magnesium in hectorite was furnished by lake waters.

Although hot springs are found in the area at the present time, it does not appear that the lithium and fluorine in the saponite were due to hot-springs activi- 
TABLE 6.--Weight percent of magnesium, lithium and fluorine in total samples from scattered locations in clay beds of Pleistocene Lake Tecopa

[Mg and Li determined by atomic absorption by Violet Merritt. F determined volumetrically by (Mrs.) Johnnie Gardner]

\begin{tabular}{|c|c|c|c|}
\hline Sample No. & $\mathrm{Mg}$ & $\mathrm{Li}$ & $\mathrm{F}$ \\
\hline 8A- - - & 10.1 & 0.082 & 0.50 \\
\hline 9--- - - & 3.00 & .021 & .11 \\
\hline 12C-ー-ー-ー & 13.4 & .080 & .74 \\
\hline D- - - - & 7.00 & .041 & .29 \\
\hline 16B- - - & 8.80 & .042 & .10 \\
\hline 17A-ー-ー-ー & 8.80 & .044 & .37 \\
\hline B------ & 13.4 & .058 & .35 \\
\hline $25 \mathrm{~A}-\cdots---$ & 4.00 & .010 & .04 \\
\hline $32 \mathrm{C}-$ & 10.1 & .034 & .31 \\
\hline 36B- - - - & 10.6 & .056 & .43 \\
\hline $36 \mathrm{E}-\cdots$ & 13.6 & .078 & .78 \\
\hline 41- & 8.80 & .060 & .50 \\
\hline
\end{tabular}

ty. Analyses of the clay-sized fractions (table 7) of sample 53 from Chicago Valley and of sample $61 \mathrm{~A}$ from the bed of the Amargosa River (fig. 14) about $29 \mathrm{~km}$ upstream from Lake Tecopa show that lithium and fluorine are both present outside the lake basin as well as within the basin, and in the same order of magnitude. The presence of lithium and fluorine in the present-day drainage suggests that these elements came from some other source than hot springs within the lake basin.

Noble, Smith, and Peck (1967) presented fluorine analyses of 164 volcanic rocks of late Miocene or Pliocene age from southern Nye County, Nev., about $160 \mathrm{~km}$ north of the area under present study. The largest amount of fluorine in any sample was 1.40 percent with the average value being about 0.13 percent. Noble (Written Commun., 1970) supplied the authors with analyses of glasses from the same area that contained about 10-40 ppm lithium. Livingston (1963) reported $0.16 \mathrm{ppm}$ lithium in the waters of the Amargosa River at Beatty, Nev., which is approximately $120 \mathrm{~km}$ upstream from Lake Tecopa.

The occurrence of lithium in such a wide area demonstrates that there is sufficient lithium available

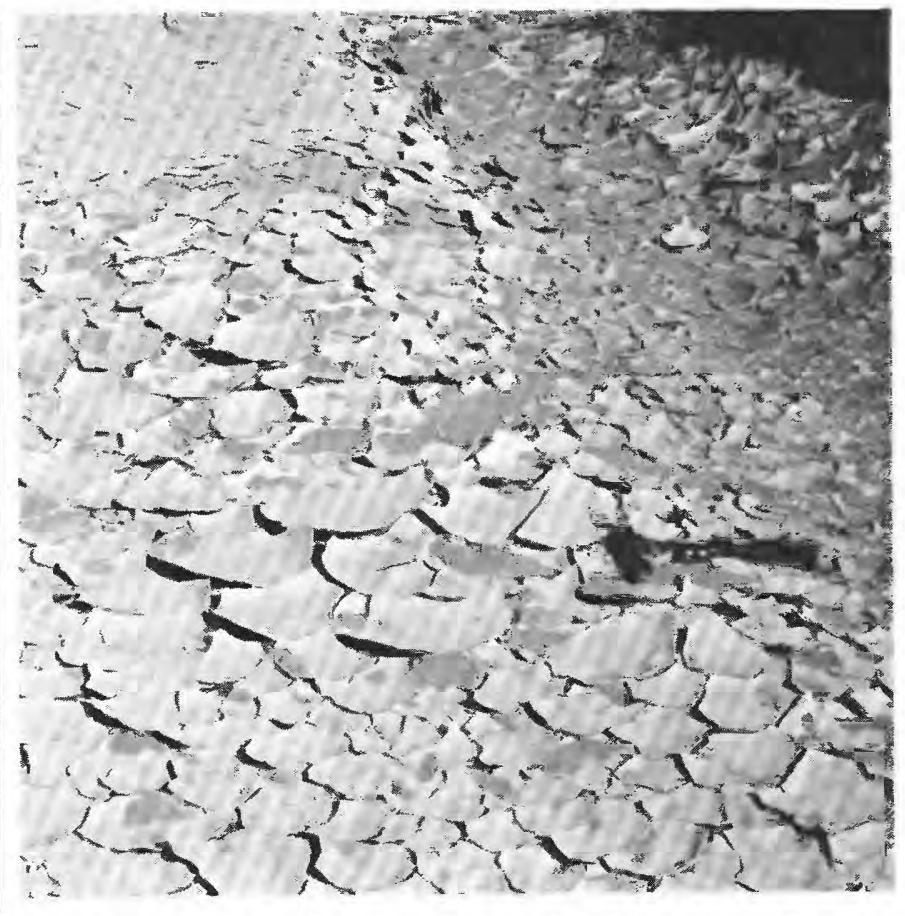

Figure 14.-Polygonal mud cracks in bed of the Amargosa River at sample locality 57 . The clay mineral crusting the entire surface is saponite.

without relying on hot springs as a source. Lithium could have been introduced into the lake by the waters of the Amargosa River.

Although hectorite has been thought to be of hydrothermal origin (Ames and others, 1958), ghassoulite from Morocco, which Faust, Hathaway, and Millot (1959) equated with hectorite, was said by Millot (1949) and Jeannette (1952) to be authigenically formed in a lake environment.

Papke $(1969,1970)$, in studies of the montmorillonite-type clay deposits in Nevada, reported that montmorillonite is the predominant clay mineral in all the deposits studied except at Ash Meadows where saponite, formed by the sedimentation and alteration of volcanic ash in lakes, is present. He did not determine if lithium was present in the samples.

The presence of other detrital minerals, such as quartz, plagioclase feldspar, and mica, in the clays plus the presence of saponite in the drainage area outside the basin indicates that the saponite is detrital. However, we cannot rule out the possibility that some saponite may have formed authigenically in the basin sediments under conditions similar to those described by Papke $(1969,1970)$ in the Ash Meadows area north of Shoshone in the Amargosa River drainage. 


\section{MONTMORILLONITE}

Montmorillonite, in the Lake Tecopa area, appears as an authigenic mineral that has two types of origin. "Amargosite," found just west of Shoshone, is a soft, sticky, white montmorillonite which, despite the desiccating effect of the present climate, is moist. This clay was formed by the hydrothermal alteration of a volcanic ash by warm springs laden with salts (Melhase, 1926). The warm springs found in the Shoshone area today may be relicts of the springs that produced the alteration.

The other type of montmorillonite is found in or very close to the tuffs deposited in the lake itself and was formed by the action of the saline lake waters on the siliceous glass of the tuff. Sheppard and Gude (1968) reported that they observed glass shards, which had been altered to zeolites, that were coated with montmorillonite. This montmorillonite is restricted and composes only a small fraction of the clay minerals. Montmorillonite is readily formed by the alteration of volcanic ash when alkalis and alkaline earths, particularly magnesium, are present (Papke, 1969). A possible reason for the small amount of montmorillonite could be that it was formed immediately after deposition of the ash (Grim, 1968) when the $\mathrm{Na}^{+}+\mathrm{K}^{+}: \mathrm{H}^{+}$activity ratio was low. Alteration of silica glasses to montmorillonite was viewed by Hay (1963) as a hydrolysis reaction releasing silica and alkali ions into solution and raising the $\mathrm{pH}$, producing conditions more favorable to formation of clinoptilolite than to formation of more montmorillonite.

Several samples taken high above tuff $A$ contained montmorillonite even though the site was not near any known tuff. These montmorillonites are usually associated with clinoptilolite. Inasmuch as these two minerals are commonly derived from volcanic ash, their presence indicates that an ash fall may have been deposited after that which formed tuff A. This evidence supports the conjecture of an ash fall as a source of silica for the sepiolite found above tuff $\mathrm{A}$.

\section{SEPIOLITE \\ TECOPA BASIN OCCURRENCE}

The Tecopa basin sepiolite is most prevalent in a narrow band near the upper limit of the lake beds at about 488-m elevation. This elevation coincides with the stratigraphic level of tuff A (fig. 15); most of the sepiolite is found within a meter or two of the tuff, usually just below its base. A few other, scattered, sepiolite-bearing sediments were detected near tuff $B$ (fig. 16), and occasionally throughout the stratigraphic column above tuff $B$ (fig. 12), especially near the lake margins (fig. 15). One sample (25 SB), located near an intermediate tuff deposited $5 \mathrm{~m}$ below tuff $\mathrm{B}$, also contained sepiolite, as did several samples in an anomalous occurrence 7.6-12 $\mathrm{m}$ above tuff $\mathrm{A}$.

Sepiolite is one of the most abundant of the possibly authigenic clay minerals found in the mud and siltstone beds adjoining the tuffs in the Tecopa basin. Little or no sepiolite has formed directly in the tuff formations, except occasionally in clay partings which were deposited in the tuffs. The only other probable authigenic clay mineral identified in or near the tuffs is the small amount of montmorillonite mentioned in the preceding section.

The sepiolite of Tecopa basin does not occur in bulk form or in pure beds. Electron micrographs of the suspended material, and X-ray diffraction patterns of the total samples show the sepiolite fibers to be dispersed among the detrital and zeolitic minerals.

As shown in the electron micrograph (fig. 6) of the clay fraction of sample 21, most sepiolite fibers are about $1 \mu$ or less long. However, some sepiolite fibers more than $2 \mu$ long have been observed in sample $1 \mathrm{~A}$ (fig. 7). The electron micrograph of a surface replica of some of the sepiolite-bearing sediment (fig. 8) shows that the fibers may occur in very small randomly oriented bundles.

An attempt was made to separate and purify the approximately 50 percent of sepiolite from sample 21 , but we were unable to remove all the saponite, illite, and poorly crystalline feldspar. An X-ray diffraction pattern of the impure sepiolite displays the broad peaks typical of many poorly crystalline sedimentarytype sepiolites. The diffraction pattern is compared in table 4 to that of a well-crystallized sepiolite. Apparently no rapid, large-scale accumulation of sepiolite has taken place at any time in this area, but rather a localized deposition in small amounts.

Some sepiolites have been found in arid, alkaline environments similar to the environment of the Lake Tecopa beds. Grim (1953) stated that sepiolite is particularly prevalent in sediments accumulating in desert lakes containing alkaline waters with slight circulatory movement. Alternatively, Parry and Reeves (1968), after noting that others (Güven and Kerr, 1966; Grim and others, 1960; Eardley and Gvodestsky, 1960; and Droste, 1961) had reported no sepiolite in their various reports on desert lakes and playas, suggested that sepiolite apparently was not as common as Grim (1953) had previously indicated. They did conclude, however, that the sepiolite found at Mound Lake, Tex., was formed in a saline, lacustrine environment by the alteration of preexisting montmorillonite. Others who have reported occurrences of sepiolite in saline, lacustrine environments include Bradley (1930), Yar- 
TABLE 7.--Lithium and fluorine in samples outside the boundaries of Pleistocene Lake Tecopa

[F determined by electrode method by D. R. Norton and (Mrs.) Johnnie Gardner; Li determined by atomic absorption by Wayne Mountjoy]

\begin{tabular}{|c|c|c|c|}
\hline $\begin{array}{c}\text { Sample } \\
\text { No. }\end{array}$ & Localities & $\begin{array}{c}F \\
\text { (percent) }\end{array}$ & $\begin{array}{c}\mathrm{Li} \\
(\mathrm{ppm})\end{array}$ \\
\hline 53---- & Chicago Valley & 0.48 & 330 \\
\hline 61A--- & $\begin{array}{c}\text { Amargosa River, } \\
29 \text { kilometers } \\
\text { upstream of } \\
\text { Pleistocene } \\
\text { Lake Tecopa. }\end{array}$ & .58 & 440 \\
\hline
\end{tabular}

zhemshkii (1949), Hardie (1968), and Papke (1972). Inasmuch as sepiolite is found in some saline, lacustrine environments but not in others, apparently a particular set of circumstances other than the basic environment is necessary for its formation.

\section{PREVIOUS WORK ON SEPIOLITE}

Siffert and Wey (1962) produced at room temperature a fibrous clay of the sepiolite type by reacting $\mathrm{Mg}^{+2}$ ions with silica in solution. The initial $\mathrm{pH}$ of the silica-magnesia solution was 11.20 and the final $\mathrm{pH}$ was 8.73. Wollast, Mackenzie, and Bricker (1968) reacted sea water with aqueous silica and produced a hydrated magnesium silicate compositionally and structurally similar to sepiolite. They also demonstrated that with a rise in $\mathrm{pH}$ of alkaline lake waters that have been concentrated by evaporation sepiolite may be precipitated if sufficient sources of magnesium and silica are available and if the dissolved silica is not removed from the waters by diatoms through biochemical processes. However, even if the silica is available, if the $\mathrm{pH}$ doesn't rise above 8.0 , sepiolite doesn't form, even matastably, but the waters tend to become saturated with amorphous silica.

Conversely, if silica activity is below the sepiolite saturation level and the $\mathrm{pH}$ is near 10, the magnesium may precipitate as brucite or hydromagnesite, or, under the proper conditions, even as dolomite. At a later time, if silica is reintroduced to the interstitial waters by dissolution of diatoms or nearby volcanic ash and dispersion of the resulting silica by circulating waters, then sepiolite may form as an authigenic mineral when the silica combines with the earlier formed magnesium mineral or with magnesium in solution.

Another determinative factor is the presence or absence of reactive aluminous phases in the waters or sediments. If ionic alumina is present, the silica and magnesium are more likely to combine with it to form alumino-silicates, such as chlorite or montmorillonite, rather than sepiolite.

In an attempt to synthesize sepiolite, Mumpton and Roy (1958) experimented with gel mixtures of the approximate composition of the average sepiolite using $\mathrm{MgO}$ (38.1 percent), $\mathrm{SiO}_{2}$ (59.6 percent), $\mathrm{Al}_{2} \mathrm{O}_{3}$ (2.3 percent), and $\mathrm{H}_{2} \mathrm{O}$. In about 100 runs at various temperatures and water pressures, they produced only montmorillonoids, talc, silica, or chloritic phases, but no sepiolite. They had started with the essential ingredients with which Hast (1956) and later Wollast, Mackenzie, and Bricker (1968) synthesized sepiolite, except that Mumpton and Roy added $\mathrm{Al}_{2} \mathrm{O}_{3}$ to the system. This would indicate that the presence of alumina in the mixture inhibits the formation of sepiolite from solution. Millot (1960), Isphording (1973), and Heron and Johnson (1966) have proposed an authigenic origin by direct precipitation for sepiolite in the natural sediments that they have studied. Precipitation could occur where the $\mathrm{pH}$ and $\mathrm{MgO}$ contents were high but $\mathrm{Al}_{2} \mathrm{O}_{3}$ was low or absent. In addition, Wollast, Mackenzie, and Bricker (1968) pointed out that sepiolite was commonly associated with carbonate sediments where alumina was low at the time of their sedimentation but not associated with shales where alumina was high.

Therefore, it is evident that in order to form sepiolite authigenically, we need a source of magnesium, a source of silica, a pH higher than 8.0 , and little or no reactive alumina present.

\section{MODES OF SEPIOLITE FORMATION}

Several possible sources were considered for the sepiolite in the Tecopa basin sediments:

1. Clastic deposition was ruled out because most of the sepiolite was concentrated in the vicinity of the ash beds; a more uniform distribution throughout the strata would be expected if the sepiolite were of clastic origin. Also, no sepiolite was found in the sediments surrounding the basin.

2. Direct diagenesis from the volcanic ash is unlikely. Little or no sepiolite was found within the tuff formations. It occurred most frequently within a few feet above or below the ash beds. Furthermore, none of the optically examined volcanic glass shards showed any alteration to sepiolite. 
3. A transformation of a parent smectite clay to a sepiolite, as suggested by Parry and Reeves (1968) for sediments in pluvial Mound Lake, Tex., was also considered. The dominant smectite mineral, a highmagnesian trioctahedral saponite, is found in all sections and stratigraphic levels of the sediments of Tecopa basin whereas sepiolite is not, the sepiolite being principally detected near the tuff beds. Although we do not believe that the saponite was transformed directly to sepiolite, we do not rule out the possibility that slight dissolution of the mineral in a high-pH environment may have supplied some of the silica and magnesium necessary to authigenically form the sepiolite.

4. The sepiolite may have been precipitated directly from solution. We contend that the principal mode of sepiolite precipitation involved postdepositional factors as well. Silica, in solution or in the form of a natural gel, may have combined with a previously formed magnesium mineral in solid or colloidal form, or may have possibly reacted with magnesium in solution in a high-pH, postdepositional environment. The latter possibility seems the most probable.

One way in which sepiolite precipitation might occur involves the direct combination of silica and magnesium as they mix in solution in the lake waters after being brought in from the lake's drainage basin. Papke (1972) suggested a sequential precipitation of dolomite and sepiolite in the Amargosa Flat, north of the study area. In this playa basin the magnesium in solution probably increased in concentration through evaporation until it began to precipitate out as dolomite. Then slowly increasing silica in solution combined with the magnesium and also precipitated sepiolite to form a combined bed about $1.2 \mathrm{~m}$ thick. A small percentage of detrital minerals was also included in the bed, and this, combined with a lack of internal bedding in the formation, indicates "rapid accumulation or, at least, constant conditions during deposition." Apparently this did not occur in the Lake Tecopa basin as no massive beds of this sort, containing sepiolite, were identified in its sediments.

Jones and VanDenburgh (1966) have shown that even though the waters of Lake Abert, a closed basin lake in southern Oregon, contained high concentrations of magnesium and silica in solution, no sepiolite or even dolomite was spontaneously precipitated therein. Droste (1961) has also found that many of the playa and closed basin lakes of southern California contain no sepiolite in their sediments. Therefore, even though the ingredients may be there, sepiolite isn't necessarily formed in these lakes in the manner described by Papke. Because of the formation in Lake
Tecopa of only small quantities of sepiolite, most of which was adjacent to the tuff beds, widespread precipitation in open water seems unlikely.

\section{SOURCES OF MAGNESIUM AND SILICA}

Sheppard and Gude (1968) have reported the presence of thin beds of dolomite in the Tecopa sediments: one below tuff $B$ and one between tuffs $B$ and $A$, both toward the central part of the basin. If there were any dolomite beds in the younger strata they have since been removed by erosion. The presence of the two thin beds would indicate that at various times the lake waters had a high concentration of magnesium in solution and a pH of well over 8.0 in order to precipitate the dolomite (Peterson and others, 1963 , and Skinner, 1963), or to convert calcite to dolomite. In addition, chemical analyses of the unaltered shards of the tuffs $A$ and $B$ showed a magnesium oxide content of 0.5 to 0.8 percent, which could become available on dissolution of the ash (Sheppard and Gude, 1968). A magnesium content of $22 \mathrm{ppm}$ was also determined in the spring water of the basin (Sheppard and Gude, oral commun., 1976). Additional magnesium in solution or as detritus was probably brought in from the north through the Amargosa River drainage areas which contains dolomite formations and significant quantities of the high-magnesium smectite, saponite. When the ash and clay beds were deposited, this magnesium from all these sources was incorporated into the sediments and interstitial water, possibly as brucite or hydromagnesite in solid or colloidal form if the pH became high enough, or as solution with a high concentration of $\mathrm{Mg}$ ions and a fairly high pH. Further concentration of magnesium would occur during periods of evaporation of the lake waters. It is evident that a sufficient supply of magnesium was available for the precipitation of sepiolite if other environmental conditions were propitious.

An adequate source of silica in solution is also readily available in the ash beds which were deposited at intervals in the lake basin and surrounding countryside. Alexander, Heston, and Iler (1954) have shown in laboratory experiments that different forms of amorphous silica, including colloidal silica, will approach a constant solubility concentration in water in the range of 100 to $140 \mathrm{ppm}$ at a temperature of $25^{\circ} \mathrm{C}$. The soluble silica is in the form of the monosilicic acid $\mathrm{Si}(\mathrm{OH})_{4}$. The solubility of the silica is almost unaffected by pH's below 9 but increases rapidly as the pH climbs, reaching about $400 \mathrm{ppm}$ at a $\mathrm{pH}$ of 10 and about 3,600 ppm at a pH of 11. An increase in temperature will also increase the amount in solution and the rate of solubility of silica. They also noted, as did Krauskopf (1956), 


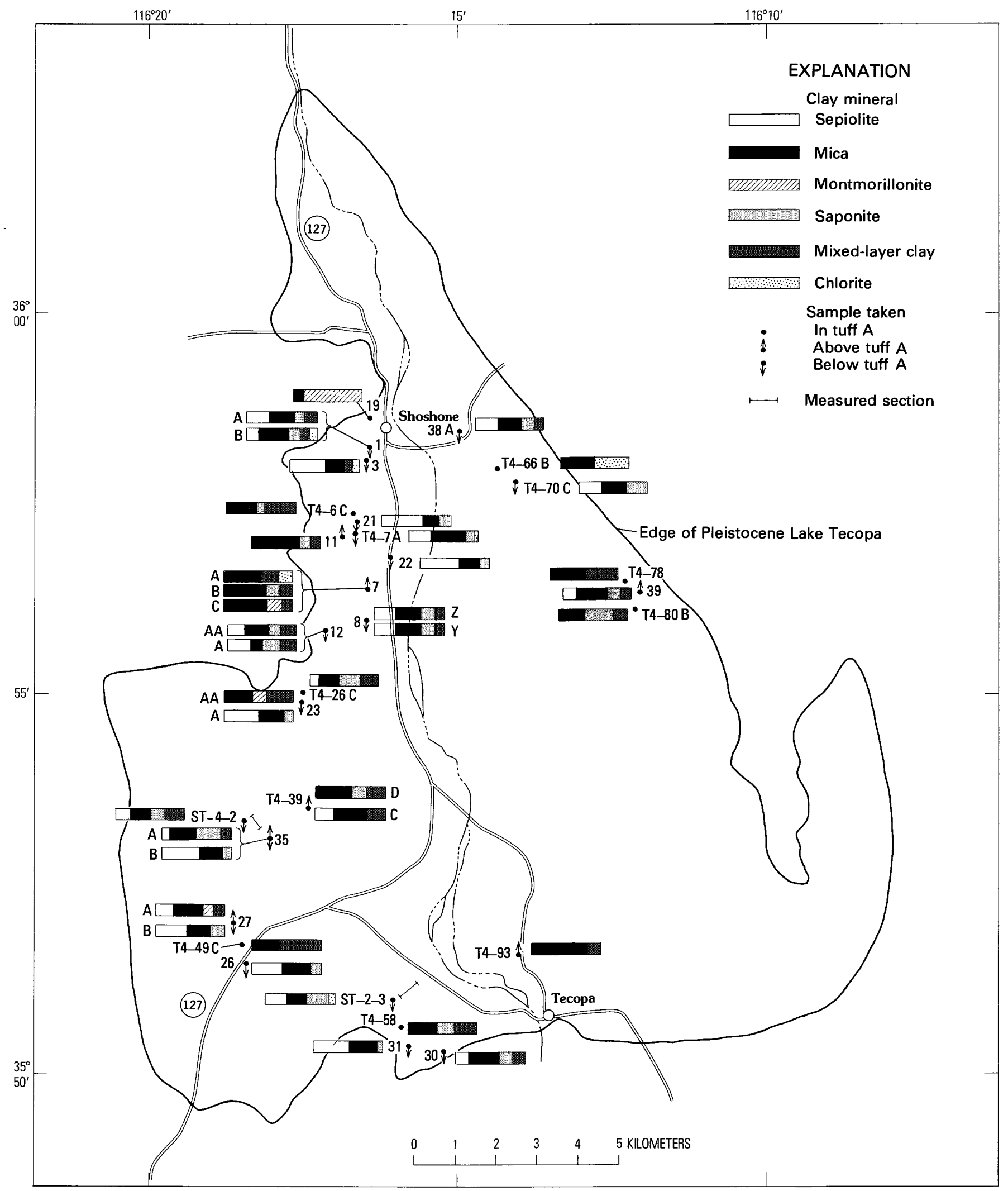

FIGURE 15.-Locality map of sample taken within $1 \mathrm{~m}$ of tuff A. Clay mineral content expressed as proportion of length of bar. 


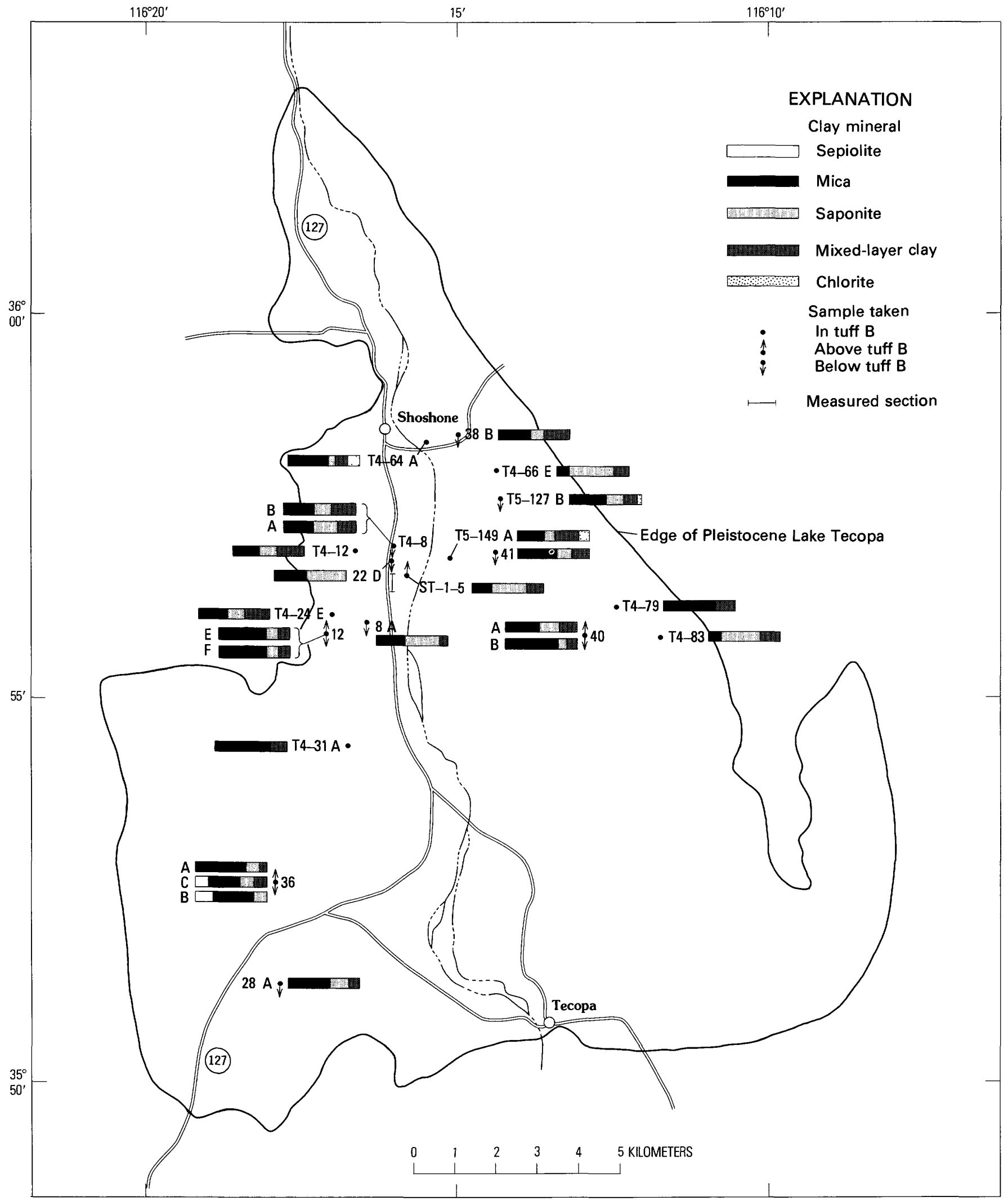

FiguRE 16.-Samples taken within $1 \mathrm{~m}$ of tuff B. Clay minerals expressed as proportion of length of bar. 
that at a pH over 9.0, colloidal, low-molecular-weight polysilicate ions are in equilibrium with the soluble monosilicic acid. As the soluble silica is removed from the solution by precipitation, the colloidal polysilicate spontaneously reverts to the soluble form and replenishes the supply of available silica in solution. Therefore, we postulate a constantly renewable source of soluble silica available in the vicinity of the ashfalls in the beds of Lake Tecopa when the pH was high owing to evaporative concentration. We do not know the ultimate concentration of the silica in the lake but some recent studies of alkaline carbonate brines in closed basins have determined natural waters to contain as much as $2,700 \mathrm{ppm}$ silica (Jones and others, 1967).

\section{SEPIOLITE FORMATION IN LAKE TECOPA}

As previously indicated, sepiolite is not found within the tuffs of the Tecopa basin but is most prevalent in sediments immediately adjacent to both the unaltered ash and the zeolitized ash. The question arises as to why sepiolite is absent from the ash but present in the other two environments.

The mudstones, siltstones, and volcanic ash were probably deposited in waters with a pH of 9 or higher. Some intermixing of the ash and the previously deposited detritals occurred at their interface. Subsequent evaporation and concentration tended to increase the salinity and $\mathrm{pH}$ in a downdip direction toward the center of the basin. However, owing to rain, snow, or the inflowing waters of the Amargosa River, incursions of fresher water into the lake basin flushed out the excess alkaline cations and lowered the $\mathrm{pH}$ of the outer, more-exposed, edges of the ash beds. This left the outer edges unaltered even as zeolitization started in downdip parts of the bed. In addition, there were periods of time when evaporation of the lake limited the waters to the central part of the basin so that the edges of the ash bed were not immersed in high-pH waters. Authigenic sepiolite, however, was still able to form beneath the unaltered ash.

Undoubtedly, in times of fairly high pH (about 8) some dissolution of the ash occurred and silica and the alkalis were disseminated, by circulating waters, downdip and into the detrital beds below and above the ash bed. The concentration of silica increased to saturation in the ash but the $\mathrm{pH}$ was not high enough nor the concentration of the magnesium great enough to precipitate sepiolite. With an influx of fresh water the $\mathrm{pH}$ dropped throughout the system. The soluble silica was then in a supersaturated state so it began to precipitate out as a colloid or as sepiolite when it came in contact with the magnesium-saturated, high-pH pore waters in adjacent detrital beds. Some sepiolite also may have formed over long periods of time when initially admixed ash dissolved in the high-pH, original pore waters of the adjacent beds and combined there with magnesium in solution to precipitate out.

Inasmuch as alumina does not readily go into solution at a $\mathrm{pH}$ of less than 9.5, probably insufficient alumina was present to precipitate zeolites either in the unaltered tuff or in any significant quantity in the adjacent beds where sepiolite occurred, as seen in the table of mineral analyses (table 2). What small amounts of zeolite were formed with the sepiolite probably were precipitated from the original pore waters which dissolved the admixed volcanic glass to provide the necessary alumina, silica, and the alkali cations. Phillipsite was most commonly found in the zeolitized tuffs or at their interface with the siltstones and claystones of the adjacent beds. Clinoptilolite was the zeolite most often found with sepiolite, sometimes with and sometimes without phillipsite.

Downdip in the basin the ash beds were zeolitized owing to more constant exposure to high-pH waters. Dissolution of the ash (and concentration of the waters) had produced a $\mathrm{pH}$ of 9-10 and the necessary soluble ingredients, silica, alumina and the alkalis, for formation of the various zeolites; but sepiolite didn't form in the ash bed owing to the presence of alumina. All or most of the alumina was used in forming zeolites or other aluminosilicates within the tuffs, or at the interface of the tuffs and the adjacent beds, as shown by Sheppard and Gude (1968). After removal of the alumina the waters disseminating into the adjacent beds were still supersaturated with silica. A drop in $\mathrm{pH}$ then caused the silica to form a colloid or to combine with the available magnesium and precipitate out as sepiolite in the pore waters near the zeolitized tuff. An alternative method to direct precipitation of the mineral from solution is as follows: Silica has a great affinity for magnesium which would tend to adsorb on the colloidal silica surface to form a hydrated magnesium silicate. Later desiccation could remove some of the water to form sepiolite.

Sepiolites found in sediments near other tuffs in the basin sequence probably were formed in the same manner as those described above. However, some sepiolite detected in other parts of the basin may have a different genesis.

Several samples, taken from sediments approximately 7.6-9.1 m, and one at $12 \mathrm{~m}$ above tuff $\mathrm{A}$, also contained sepiolite. Sample 4, containing approximately 40 percent sepiolite was taken about $1.3 \mathrm{~km}$ southwest of Shoshone, in the northern part of the basin and 7.6 $\mathrm{m}$ above the tuff $\mathrm{A}$. It is possible that a thin ash bed 
might have been deposited in the lake waters at that time, to act as a silica supply for sepiolite. No trace of one was found by the authors at this location or at the other locations around the basin at that altitude where the samples containing sepiolite were collected. However, several nonsepiolite-bearing samples taken at those altitudes, $2,20 \mathrm{~A}, 20 \mathrm{~B}$, and 24 , contained dioctahedral montmorillonite and clinoptilolite, both of which are products of ash devitrification.

Under the proper conditions of $\mathrm{pH}$, magnesium concentration, and silica saturation, it is possible that at the locations listed in the preceding paragraph and other anomalous locations far from ash beds a direct precipitation from solution may have occurred as described by Papke (1972). However, no real evidence of this was found. An alternative possibility for a silica source for sepiolite precipitation would be the presence of abundant diatom colonies in the lake. Sheppard and Gude (1968) have stated that 42 species of diatoms were identified in their fossil locality 5 about $1.6 \mathrm{~km}$ northeast of the site of sample 4 , at about $488+\mathrm{m}$ altitude. Some of the diatoms were identified as "fresh water" types which would correlate with their location in the north end of the basin where the Amargosa River entered, supplying fresh water from a considerable drainage area to the north.

A flourishing colony of diatoms might remove a considerable quantity of silica from solution in the lake waters (Phillips and VanDenburgh, 1971). If the supply of fresh water diminished radically, the salinity would rise and kill off the colony causing decay of the organisms and a rapid return of silica to the environment. With a high enough $\mathrm{pH}$ and source of magnesium, a localized precipitation of sepiolite might occur wherever a colony had been located. Sample 37 in the same approximate area as diatom fossil locality 5 , and altitude as sample 4 (7.6 $\mathrm{m}$ above $\mathrm{A}$ tuff), has an ostracode bed that indicates a fresh-water environment. Sample area 39 on the east side of the basin at approximately the same altitude as sample area 4 also contains fresh water ostracodes, as well as a small amount of sepiolite. Two other sample sites, 50 and 56, containing sepiolite, are in an area where fresh water would intermittently incur and are at about the same altitude as the site of sample 4 . Therefore, although diatoms were not actually found at the sepiolite sites at that lake level, 7.6-9.1 $\mathrm{m}$ above tuff $\mathrm{A}$, we cannot rule out the possibility that they were a source of the necessary silica for sepiolite precipitation in the high$\mathrm{pH}$, magnesium-concentrated pore waters of a later lake phase.

On the basis of our laboratory experimentation and field evidence we conclude that the sepiolite found in the Tecopa basin is of authigenic origin. The volcanic ash beds, and possibly in some cases fossil diatoms, supplied the necessary silica in solution or colloidal form to combine with magnesium in a high salinity, high-pH lake-water environment. Sepiolite may have precipitated directly from solution in open lake waters at various times after the deposition of tuff $A$ but no proof is available.

\section{DISCUSSION \\ SEQUENGE OF EVENTS}

During the middle to late Pleistocene, the Amargosa River was dammed by alluvial fan deposits south of the present-day site of Tecopa, Calif. (Sheppard and Gude, 1968). Waters began to accumulate behind the dam with simultaneous deposition of fine-grained detritus. Figure 12 shows that the clay minerals deposited below the tuff $\mathrm{C}$ were mostly micas (or illites), saponite, and mixed layered material. Some small beds of volcanic ash were laid down at this time also.

Later, the ash fall which subsequently produced tuff $\mathrm{C}$ was laid down, followed by the deposition of more detrital mudstones. The deposition of these mudstones was also interrupted periodically by light ash falls, one of which was large enough that it has been termed the "intermediate tuff".

The ash fall which produced tuff $B$ was next deposited. By this time the concentration of the magnesium and the $\mathrm{pH}$ of the lake waters had increased to the point that some sepiolite was being formed by the reaction of the magnesium-rich waters and the silica from the ash falls which had been taken into solution by the lake waters. The salinity of the water would not have increased very rapidly at first but as the lake grew and covered a greater area, the enlarged surface area would have increased evaporation to produce greater salinity.

More detrital material was deposited as mudstones, followed by another ash fall which produced tuff A. Again, magnesium-bearing waters of the lake combined with the plentiful silica to produce even more sepiolite than was produced in associaton with tuff $B$. This was the last major ash fall although the presence of montmorillonite and sepiolite above tuff $A$ indicates that there later was at least one minor ash fall. Detrital material was deposited as long as the lake existed.

\section{CONCLUSIONS}

Most of the minerals which make up the mudstones of the Tecopa basin are detrital in origin. They consist of quartz, plagioclase feldspar, some of the calcite and dolomite, and the clay minerals mica, illite, chlorite, 
the lithian saponite and mixed layered combinations of these. All these minerals are found areally throughout, and at all stratigraphic levels of, the Tecopa sediments as well as in the basin drainage area. This would tend to preclude an authigenic origin for them in the basin.

The clay minerals brought into the lake as detritus from the drainage area were not affected by diagenesis. No differences can be detected between them and the clay minerals found along the tributaries. If there were any dissolution or alteration of the clays, the amount was negligible. This corroborates the findings of Droste (1961) who, after comparing the clay minerals from 45 playas in the Mojave Desert with the clay minerals from surrounding areas, concluded that clays deposited in alkaline lakes reflected the source rocks rather than diagenesis.

Possibly some of the lithian saponite was formed by diagenesis of montmorillonite, as suggested by Papke for the Amargosa Flat sediments; however, most of it is considered to be detrital.

The minerals that we consider to be authigenic include much of the calcite and dolomite, sepiolite, magadiite, potassium feldspar, montmorillonite, zeolites, and the saline minerals.

During this entire process, the calcium and $\mathrm{CO}_{2}$ in the lake waters were combining to precipitate the calcite which is almost ubiquitous. It is especially abundant at the north end of the lake where the calcium-bearing waters of the Amargosa River came into contact with the carbonate waters of the lake. The calcite is less abundant in the southwestern part of the lake near the entrance of Greenwater valley.

Only small amounts of dolomite are found in the lake beds although magnesium was probably present in its waters throughout the life of the lake and became more concentrated as the salinity of the waters increased. Dolomite is not readily precipitated from magnesiumrich solutions (Peterson and others, 1963, Peterson and others, 1966, Clayton and others, 1968), although calcite is readily precipitated if calcium is present. Any dolomite that was precipitated would have been formed very slowly. The thin beds of finely crystalline dolomite recognized in the basin by Sheppard and Gude (1968) probably are authigenic in origin. Their presence would imply water conditions of high salinity and $\mathrm{pH}$ and a good concentration of magnesium.

The formation of authigenic sepiolite also requires a special environment as shown in experimentation by Siffert and Wey (1962), Wollast, Mackenzie, and Bricker (1968), and Mumpton and Roy (1958). It needs a source of silica and of magnesium in high-pH waters but with the absence of reactive aluminous phases. In the closed basin of Tecopa, the $\mathrm{pH}$ of the lake waters reached at least 8.0, owing to evaporation and the con- centration of magnesium and silica and various salts. The dissolution of volcanic ash, which periodically was deposited in the lake, then supplied the necessary silica to combine with magnesium in forming the sepiolite. The reactive alumina, which was also released by dissolution of the ash, served a twofold purpose. First, it was essential in the formation of the zeolites within the tuff beds and at their interface with the detrital beds. Second, the alumina prevented the precipitation of sepiolite within the tuffs but did not inhibit the dissemination of the silica-supersaturated, and by then alumina-depleted, waters into the surrounding sediments where sepiolite formed in the high-pH, magnesium-saturated pore waters. The dissolution of diatoms may have supplied the necessary silica for some sepiolite formation where volcanic ash was not available.

Grim, Kulbicki, and Carozzi (1960) stated that the clay minerals rich in magnesium, such as sepiolite, probably would not form in an environment of highsodium content. However, in the mudstones of Lake Tecopa the sepiolite content is well established, dolomite is present in small quantities, and yet magadiite, a hydrous sodium silicate which is precipitated from silica-rich sodium waters (Eugster, 1969), is found in one area at about the same stratigraphic level as the sepiolite.

Determination of how widespread the magadiite formation was in the basin because of subsequent erosion and leaching action is impossible; but, because of the magnesium content of the lake waters and because of the occurrence of magadiite only in one part of the basin, we conclude that this was a local occurrence caused by the presence of sodium-rich springs in this area making contact with the silica-bearing lake waters.

Authigenic, dioctahedral montmorillonite is not as widespread in basin sediments as detrital, trioctahedral smectite saponite. It is found in a few localities where diagenesis of the volcanic ash has occurred to form clinoptilolite and montmorillonite. Sheppard and Gude (1968) also reported some montmorillonite coatings on shards associated with other zeolites such as phillipsite. The other occurrence of montmorillonite, "amargosite," is caused by the hydrothermal alteration of volcanic ash by hot-spring waters. This unique mineral formation was found in the vicinity of the town of Shoshone.

Other authigenic minerals, such as the zeolites and potassium feldspar, are found scattered throughout the basin in small quantities in the detrital sediments, and larger more concentrated amounts are found in or near the tuffs. Sheppard and Gude (1968) have described the formation of these minerals in their paper on the 
authigenic silicates in the tuff formations of Tecopa basin.

\section{REFERENCES CITED}

Alexander, G. B., Heston, W. M., and Iler, R. K., 1954, The solubility of amorphous silica in water: Journal of Physical Chemistry, v. 58, p. $453-455$.

Ames, L. L., Jr., Sand, L. B., and Goldich, S. S., 1958, A contribution on the Hector, California bentonite deposit: Economic Geology, v. 53, no. 1, p. 22-37.

Bailey, G. E., 1902, The saline deposits of California: California State Mining Bureau Bulletin 24, $216 \mathrm{p}$.

Blackwelder, Eliot, 1936, Pleistocene Lake Tecopa [abs.]: Geological Society America Proceedings for 1935, p. 333.

1954, Pleistocene lakes and drainage in the Mojave region, southern California, p. 35-40, Pt. 5 in Chapt. 5 of R. H. Jahns, ed., Geology of southern California: California Department Natural Resources, Division Mines Geology Bulletin 170, p. $35-40$.

Blanc, R. P., and Cleveland, G. B., 1961a, Pleistocene lakes of southeastern California, Pt. 1: California Division Mines and Geology Mineral Information Service, v. 14, no. 4, p. 1-8.

1961b, Pleistocene lakes of southeastern California, Pt. 2: California Division Mines and Geology Mineral Information Service, v. 14, no. 5, p. 1-7.

Bradley, W. H, 1930, The occurrence and origin of analcite and meerschaum beds in the Green River Formation of Utah, Colorado, and Wyoming: U.S. Geological Survey Professional Paper 158-A, p. 1-7.

Bricker, O. P., 1969, Stability constants and Gibbs free energies of formation of magadiite and kenyaite: American Mineralogist, v. 54, nos. 7-8, p. 1026-1033.

Cahoon, H. P., 1954, Saponite near Milford, Utah: American Mineralogist, v. 39, nos. 3-4, p. 222-230.

Caillère, Simonne, and Hénin, S., 1957, Sur la Presence à Diélette d'une saponite à texture fibreuse: Société Française de Minéralogie et de Cristallographie Bulletin, v. 80, no. 10-12, p. 543-545.

Campbell, M. R., 1902, Reconnaissance of the borax deposits of Death Valley and Mohave Desert: U.S. Geological Survey Bulletin 200, 23 p.

Clayton, R. N., Jones, B. F., and Berner, R. A., 1968, Isotope studies of dolomite formation under sedimentary conditions: Geochimica et Cosmochimica Acta, v. 32, no. 4, p. 415-432.

Dietrich, W. F., 1928, The clay resources and ceramics industry of California: California Division Mines and Mining Bulletin 99, $383 \mathrm{p}$.

Droste, J. B., 1961, Clay minerals in the playa sediments of the Mo jave Desert, California: California Division Mines Special Report 69, 19 p.

Eardley, A. J., and Gvosdetsky, Vasyl, 1960, Analysis of Pleistocene core from Great Salt Lake, Utah: Geological Society of America Bulletin, v. 71, no. 9, p. 1323-1344.

Eugster, H. P., 1967, Hydrous sodium silicates from Lake Magadi, Kenya: precursors of bedded chert: Science, v. 157, p. $1177-1180$

1969, Inorganic bedded cherts from the Magadi area, Kenya: Contributions to Mineralogy and Petrology, v. 22, p. 1-31.

Fahey, J. J., Ross, Malcolm, and Axelrod, J. M., 1960, Loughlinite, a new hydrous sodium magnesium silicate: American Mineralogist, v. 45, nos. 3-4, p. 270-281.
Faust, G. T., Hathaway, J. C., and Millot, Georges, 1959, A restudy of stevensite and allied minerals: American Mineralogist, v. 44, nos. 3-4, p. 342-370.

Foshag, W. F., and Woodford, A. O., 1936, Bentonitic magnesian clay mineral from California: American Mineralogist, v. 21, no. 4, p. 238-244.

Frondel, Clifford, 1962, The system of mineralogy, v. 3 of Silica minerals: New York, John Wiley and Sons, Inc.

Grim, R. E., 1953, Clay mineralogy: New York, McGraw-Hill Book Company, Inc., $384 \mathrm{p}$.

1968, Clay mineralogy (2d ed.): McGraw-Hill Book Company, $596 \mathrm{p}$.

Grim, R. E., Kulbicki, Georges, and Carozzi, A. V., 1960, Clay mineralogy of the sediments of the Great Salt Lake, Utah: Geological Society of America Bulletin, v. 71, no. 4, p. 515-520.

Güven, Necip, and Kerr, P. F., 1966, Selected Great Basin playa clays: American Mineralogist, v. 51, no. 7, p. 1056-1067.

Hardie, L. A., 1968, The origin of the Recent non-marine evaporite deposit of Sabine Valley, Inyo County, California: Geochimica et Cosmochimica Acta, v. 32, no. 12, p. 1279-1301.

Hast, Nils, 1956, A reaction between silica and some magnesium compounds at room temperatures and at $+37^{\circ} \mathrm{C}$ : Arkiv. Kemi., v. 9, p. 343-360.

Hay, R. L., 1963, Stratigraphy and zeolitic diagenesis of the John Day Formation of Oregon: California University Publications in Sciences, v. 42, p. 199-250.

Heron, S. D., Jr., and Jolinson, H. S., Jr., 1966, Clay mineralogy stratigraphy, and structural setting of the Hawthorn Formation, Cooswahatchie district, South Carolina: Southeastern Geology, v. 7, no. 2, p. 51-63.

Isphording, W. C., 1973, Discussion of the occurrence and origin of sedimentary palygorskite-sepiolite deposits: Clays and Clay Minerals, v. 21, p. 391-401.

Jeannette, A., 1952, Argiles smectiques et rhassoul, in Geologie des gîtes minéraux Marocains: XIX Cong. Géol. Internat. Mon. Régional, Ser. 3, Maroc no. 1, p. 371-383.

Jones, B. F., 1961, Zoning of saline minerals at Deep Spring Lake, California: U.S. Geological Survey Professional Paper 424-B, p. B199-B202.

Jones, B. F., Rettig, S. L., and Eugster, H. P., 1967, Silica in alkaline brines: Science, v. 158, p. 1310-1314.

Jones, B. F., and VanDenburgh, A. S., 1966, Geochemical influences on the chemical character of closed lakes, in Symposium of Garda, v. 1, October 9-15, 1966, Hydrology of lakes and reservoirs: International Association of Scientific Hydrology Publication 70, p. 435-446.

Kerr, P. F., Hamilton, P. K., Hill, R. J., and others, 1950, Analytical data on reference clay niaterials: American Petroleum Institute, Project 49, Clay Mineral Standards, Preliminary Report 7, 160 p.

Kerr, P. F., and Langer, A. M., 1965, Mineralogical features of Mojave Desert playa crusts, in J. T. Neal, ed., Geology, mineralogy, and hydrology of U.S. playas: U.S. Air Force Cambridge Research Laboratories Environmental Research Paper 96, p. 31-72.

Kesler, T. L., 1960, Lithium raw materials, in Industrial minerals and rocks, 3d ed.: American Institute of Mining, Metallurgical and Petroleum Engineers, p. 521-531.

Krauskopf, K. B., 1956, Dissolution and precipitation of silica at low temperatures: Geochimica et Cosmochimica Acta, v. 10, p. 1-26.

Livingston, D. A., 1963, Chemical composition of rivers and lakes: U.S. Geological Survey Professional Paper 440-G, 64 p.

McAtee, J. L., Jr., House, R., and Eugster, H. P., 1968, Magadiite from Trinity County, California: American Mineralogist, v. 53, nos. 11-12, p. 2061-2069. 
Mallory, E. C., Jr., 1965, Leachable silica and alumina in streambed clays, in Geological Survey research 1965: U.S. Geological Survey Professional Paper 525-B, p. B170-B174.

Mason, J. F., 1948, Geology of the Tecopa area, southeastern California: Geological Society of America Bulletin, v. 59, no. 4, p. 333-352.

Melhase, John, 1926, Mining bentonite in California: Engineering and Mining Journal Press, v. 121, p. 837-842.

Midgley, H. G., and Cross, K. A., 1956, Thermal reactions of smectites: Clay Minerals Bulletin, v. 3, no. 16, p. 79-90.

Miller, R. R., 1946, Correlation between fish distribution and Pleistocene hydrography in eastern California and southwestern Nevada, with a map of the Pleistocene waters: Journal of Geology, v. 54, no. 1, p. 43-53.

Millot, Georges, 1949, Jurassique Djebel ghassoul, in Relations entre la constitution et la genèse des roches sédimentaires argileuse: Geol. app. et prospection minière, Nancy II, p. 199-201.

1960 [1962], Crystalline neoformation of clays and silica: Proc. Symposium Basic Sci. France-U.S., New York, New York Univ. Press, p. 180-191.

Mumpton, F. A., and Roy, Rustum, 1958, New data on sepiolite and attapulgite: Clays and Clay Minerals, v. 5, p. 136-143.

Noble, D. C., Smith, V. C., and Peck, L. C., 1967, Loss of halogens from ctystallized and glassy silicic volcanic rocks: Geochimica et Cosmochimica Acta, v. 31, p. 215-223.

Noble, L. F., 1926, Note on a colemanite deposit near Shoshone, California, with a sketch of the geology of a part of Amargosa Valley: U.S. Geological Survey Bulletin 785-D, p. 63-73.

1934, Rock formations of Death Valley, California: Science, new ser., v. 80, p. 173-178.

Noble, L. F., Mansfield, G. R., and others, 1922, Nitrate deposits in the Amargosa region, southeastern California: U.S. Geological Survey Bulletin 724,99 p.

Norton, J. J., 1965, Lithium-bearing bentonite deposit, Yavapai County, Arizona, in Geological Survey research 1965: U.S. Geological Survey Professional Paper 525-D, p. D163-D166.

Papke, K. G., 1969, Montmorillonite deposits in Nevada: Clays and Clay Minerals, v. 17, no. 4, p. 211-222.

1970, Montmorillonite, bentonite, and fuller's earth deposits in Nevada: Nevada Bureau of Mines Bulletin 76, $47 \mathrm{p}$.

1972, A sepiolite-rich playa deposit in southern Nevada: Clays and Clay Minerals, v. 20, no. 4, p. 211-215.

Parry, W. T., and Reeves, C. C., Jr., 1968, Sepiolite from pluvial Mound Lake, Lynn and Terry Counties, Texas: American Mineralogist, v. 53, nos. 5-6, p. 984-993.

Peterson, M. N. A., Bien, G. S., and Berner, R. A., 1963, Radiocarbon studies of recent dolomite from Deep Spring Lake, California: Journal of Geophysical Research, v. 68, no. 24, p. 6493-6505.

Peterson, M. N. A., von der Borch, C. C., Bien, G. S., 1966, Growth of dolomite crystals: American Journal of Science, v. 264, no. 4, p. 257-272.
Phillips, K. N., and VanDenburgh, A. S., 1971, Hydrology and geochemistry of Abert, Summer, and Goose Lakes, and other closed-basin lakes in south-central Oregon: U.S. Geological Survey Professional Paper 502-B, 86 p.

Rooney, T. P., Jones, B. F., and Neal, J. T., 1969, Magadiite from Alkali Lake, Oreg.: American Mineralogist, v. 54, nos. 7-8, p. 1034-1043.

Ross, C. S., and Hendricks, S. B., 1945 [1946], Minerals of the montmorillonite group, their origin and relation to soils and clays: U.S. Geological Survey Professional Paper 205-B, p. 23-79.

Sand, L. B., and Ames, L. L., Jr., 1958, Altered siliceous volcanics as a source of refractory clay: Clays and Clay Minerals, v. 5., p. 39-45.

Sand, L. B., and Regis, A. J., 1960, Report on a vein montmorillonite from Tooele County, Utah [abs.]: Geological Society of America Bulletin, v. 71, no. 12, pt. 2, p. 1965.

Schroter, G. A., and Campbell, Ian, 1942, Geological features of some deposits of bleaching clays: American Institute of Mining and Metallurgical Engineers Transactions, v. 148, p. 178-208.

Shawe, D. R., Mountjoy, Wayne, and Duke, Walter, 1964, Lithium associated with beryllium in rhyolitic tuff at Spor Mountain, western Juab County, Utah, in Geological Survey research 1964: U.S. Geological Survey Professional Paper 501-C, p. C86-C87.

Sheppard, R. A., and Gude, A. J., 3d., 1968, Distribution and genesis of authigenic silicate minerals in tuffs of Pleistocene Lake Tecopa, Inyo County, California: U.S. Geological Survey Professional Paper 597, 38 p.

Siffert, Bernard and Wey, Raymond, 1962, Synthèse d'une sépiolite à température ordinaire: Acad. Sci. (Paris) Comptes Rendus de l'Academie des Sciences, v. 254, p. 1460-1462.

Skinner, H. C. W., 1963, Precipitation of calcian dolomites and magnesian calcites in the southeast of South Australia: American Journal of Sciences 261, p. 449-472.

Strese, H., and Hofmann, Ulrich, 1941, Synthesis of magnesium silicate gels with two-dimensional structure: Zeitschrift für anorganische und allgemeine Chemie, v. 247, p. 65-69 [Chemistry Abstracts, v. 36, 5073-4 (1942)].

Thompson, D. G., 1929, The Mohave Desert region, California: U.S. Geological Survey Water-Supply Paper 578, 759 p.

Wollast, Roland, MacKenzie, F. J., and Bricker, O. P., 1968, Experimental precipitation and genesis of sepiolite at earthsurface conditions: American Mineralogist, v. 53, nos. 9-10, p. 1645-1662.

Wright, L. A., and Troxel, B. W., 1954, Western Mojave Desert and Death Valley region, Geologic Guide no. 1 of R. H. Jahns, ed., Geology of southern California: California Department Natural Resources Division Mines Bulletin 170, $50 \mathrm{p}$.

Yarzhemskîi, Ya. Ya., 1949, Petrographic character of recent salt sediments (in Russian): Doklady Akad. Nauk., SSSR., v. 68, p. 1085-1088 [Chem. Abs., v. 44, 2901b (1950)]. 